Check for updates

Cite this: RSC Adv., 2020, 10, 13126

\section{Synthesis of homo- and hetero-metallic cobalt and zinc nano oxide particles by a calcination process using coordination compounds: their characterization, DFT calculations and capacitance behavioural study $\dagger$}

\author{
Sartaj Tabassum, (DD *ab Mohammad Usman, ${ }^{a}$ Hamad A. Al-Lohedan, ${ }^{b}$ \\ Mahmood M. S. Abdullah, (D) ${ }^{\mathrm{b}}$ Mohamed A. Ghanem, (D) ${ }^{\mathrm{b}}$ Merfat S. Al-Sharif ${ }^{\mathrm{b}}$ \\ and Mohd Sajid Ali (D) ${ }^{\mathrm{b}}$
}

\begin{abstract}
Nano cobalt and porous zinc-cobalt oxide particles were synthesized using the concept of coordination compounds of the type $\left[M(॥) L, L^{\prime}\right]$ (where $M(॥)=C o(॥)$ \& $Z n(॥) L=4$-hydroxy benzaldehyde and $L^{\prime}=$ piperazine) and were thoroughly characterized. Because the precursors are coordination compounds possessing specific geometry in the crystal lattice, uniform and appropriately sized homo- and heterometallic nanocrystals of $\mathrm{CO}_{3} \mathrm{O}_{4}$ and $\mathrm{ZnO} \cdot \mathrm{CO}_{3} \mathrm{O}_{4}$ were obtained after a thermal process. The homo and hetero composite particles were characterized by transmission electron microscopy (TEM), scanning electron microscopy (SEM), energy dispersive X-ray analysis (EDX), X-ray diffraction (XRD), FT IR spectroscopy and electrochemistry. The paramagnetic chemical shift of the methyl protons in DMSO due to the nanoparticles was studied by NMR spectroscopy, which indicated that the cobalt particles were ferromagnetic. The structural design modification and surface area of $\mathrm{CO}_{3} \mathrm{O}_{4}$ was improved by adding the $\mathrm{ZnO}$ component. DFT calculations were done to validate the nano structure. Supercapacitance ability of the nanoparticles was studied by cyclic voltammetry, and electrochemical calculations were performed to determine the microelectronic characteristics of the material. The specific capacitance was estimated at 207.3 and $51.1 \mathrm{~F} \mathrm{~g}^{-1}$ for the $\mathrm{ZnO} \cdot \mathrm{CO}_{3} \mathrm{O}_{4}$ and $\mathrm{CO}_{3} \mathrm{O}_{4}$ electrodes, respectively. Clearly, $\mathrm{ZnO} \cdot \mathrm{CO}_{3} \mathrm{O}_{4}$ exhibited a much higher specific capacitance than the $\mathrm{CO}_{3} \mathrm{O}_{4}$ nanocrystal, which was attributed to better conductivity and higher surface area. The capacitance activity showed multifold enhancement due to the porous nature of $\mathrm{Zn}$ oxide in the heterometallic nano $\mathrm{ZnO} \cdot \mathrm{CO}_{3} \mathrm{O}_{4}$ composite.
\end{abstract}

Received 7th February 2020 Accepted 24th March 2020 DOI: $10.1039 / \mathrm{dOra01191f}$ rsc.li/rsc-advances pollutants and in electro catalysis for oxygen hydrogen generation, and very recently, cobalt nano oxides were used as probes in medical diagnostic devices. ${ }^{\mathbf{1 - 4}}$ A glucose sensor of cobalt oxide nano rods was prepared by Kuo-Chuan Ho et al. for the non-enzymatic detection of glucose. ${ }^{5}$ The interesting applications of nano transition oxides depend on their size and different structural morphologies including nanotubes, nanorods, nano cubes and meso porous structures.

Many synthetic techniques and routes have been utilized to prepare these nanomaterials, including sol-gel methods, ${ }^{6}$ solvothermal synthesis, ${ }^{7}$ thermal decomposition of cobalt precursors, ${ }^{8}$ sonochemical methods, ${ }^{9}$ co-precipitation ${ }^{10}$ and microwaveassisted methods. ${ }^{11}$ Most of these methods are not feasible for large-scale production owing to the expensive and toxic chemicals required and the use of complex instruments. Researchers are looking for more facile synthetic routes to obtain new nanomaterials of mixed valence oxides by choosing appropriate precursors, which have potential advantages including high yield 
of pure products, the absence of solvents, low energy consumption and functional efficiency. Herein, we have undertaken the task of preparing homo and hetero-metallic $\mathrm{Co}_{3} \mathrm{O}_{4}, \mathrm{ZnO} \cdot \mathrm{Co}_{3} \mathrm{O}_{4}$ mixed-valence oxides possessing different structural morphologies and electrochemical behaviour. ${ }^{\mathbf{1 2 , 1 3}}$ In this work, we report a new modified calcination process that uses the coordination chemistry concept of employing piperazine and aldehyde with metal salts to obtain a uniform single crop of nano $\mathrm{Co}_{3} \mathrm{O}_{4}$ and porous $\mathrm{ZnO} \cdot \mathrm{Co}_{3} \mathrm{O}_{4}$ crystals. The heterobimetallic oxides show multifold enhanced activities (catalytic and capacitance properties) compared to monometallic nano oxide. ${ }^{14}$ The obtained heterobimetallic nanomaterials have mixed oxidation sates, which helps build up the inner electric field at the junction interface and create more pores in the porous material. ${ }^{15,16}$

\section{Experimental}

\subsection{Materials}

Chemicals, including $\mathrm{CoCl}_{2}, \mathrm{Zn}\left(\mathrm{NO}_{3}\right)_{2} \cdot 6 \mathrm{H}_{2} \mathrm{O}$ (4-hydroxy benzaldehyde), and piperazine were purchased from Sigma Aldrich, USA. Power X-ray diffraction (XRD) of the products was measured using a Philips X'Pert PRO MPD diffractometer at a scanning rate of $4^{\circ} \mathrm{min}^{-1}$, with $2 \alpha$ ranging from $10^{\circ}$ to $70^{\circ}$, using $\mathrm{Cu} \mathrm{K} \alpha$ radiation (=1.5406 $\AA$ ). The morphologies of the samples were studied by scanning electron microscopy (SEM) (JEOL SM5600LV) at $20 \mathrm{kV}$. The powders were ultrasonicated in ethanol, and a drop of the suspension was dried on a carboncoated microgrid. Transmission electron microscopy (TEM) observations were performed with a JEM 100CX-II microscope operated at $100 \mathrm{kV}$. NMR spectra were recorded in DMSO $\mathrm{d}_{6}$ on a Jeol $400 \mathrm{MHz}$ NMR spectrometer. Thermal studies were performed using a TGA/SDTA 851e (Mettler Toledo) thermogravimetric analyser in ambient atmosphere from $20{ }^{\circ} \mathrm{C}$ to $700{ }^{\circ} \mathrm{C}$ at a heating rate of $10{ }^{\circ} \mathrm{C} \mathrm{min}^{-1}$. Electrochemical measurements were performed using a potentiostat (AutolabPGSTAT101) in a standard three-electrode setup, with a working electrode of $\mathrm{CoZnO}_{2}$ and $\mathrm{Co}_{3} \mathrm{O}_{4}$ nanocrystals $(50 \mu \mathrm{g}$ dispersed in water and isopropanol solution) loaded on a carbon paper substrate (SIGRACET®, grade GDL-24BC, geometric area $1 \times 1 \mathrm{~cm}^{2}$ ), as well as a Pt mesh and a saturated calomel electrode (SCE) as the counter and reference electrodes, respectively.

\subsection{Synthesis of precursors and nanoparticles}

The mono and heterobimetallic nanoparticles were prepared by a modified coordination chemistry procedure. A methanolic solution of the metal salt $\mathrm{Co}(\mathrm{II}) / \mathrm{Zn}$ (II), aldehyde and piperazine at a $1: 1: 1$ molar ratio was refluxed for $2 \mathrm{~h}$ in a $100 \mathrm{~mL}$ round bottom flask (Scheme 1). The blue cobalt complex and white powder of the zinc compound were obtained, and adducts were washed with methanol and hexane and were dried under vacuum. The prepared coordination compounds were characterized by FTIR and mass spectrometry on the basis of the preliminary characterization (Scheme 1). [Co(II)benzaldehyde - piperazine $\left.\cdot \mathrm{H}_{2} \mathrm{O}\right] 0.5 \mathrm{H}_{2} \mathrm{O} ; \mathrm{mp} 300{ }^{\circ} \mathrm{C} \mathrm{d} / z$ 292.15(293.20) [M-L-L'1.5 $\left.\mathrm{H}_{2} \mathrm{O}+\mathrm{H}\right]$. [Zn(II)benzaldehyde $\cdot$ piperazine $\cdot \mathrm{H}_{2} \mathrm{O}$ ]; mp $235{ }^{\circ} \mathrm{C} \mathrm{d} m / z$ 289.65(293.19) $\left[\mathrm{Zn}-\mathrm{L} \cdot \mathrm{L}^{\prime} \cdot \mathrm{H}_{2} \mathrm{O}-3 \mathrm{H}^{+}\right.$]. The FTIR bands at 498, 877, 998, 1224, 1342, 1413, 1450, 1584, 2825, 3196 and $3556 \mathrm{~cm}^{-1}$ are due to the $\mathrm{C}=\mathrm{O}, \mathrm{C}-\mathrm{C}, \mathrm{C}-\mathrm{H}, \mathrm{C}-\mathrm{N}$ and $\mathrm{H}_{2} \mathrm{O}$ vibration and bending modes. The broad bands in the 3556$3196 \mathrm{~cm}^{-1}$ range in the spectra of the precursors have been attributed to the stretching vibrations of $\mathrm{H}_{2} \mathrm{O}, \mathrm{OH}$ and $\mathrm{NH}$. The band at $2825 \mathrm{~cm}^{-1}$ was due to the $\mathrm{C}-\mathrm{H}$ stretching mode, and the bands at 1342 and $1584 \mathrm{~cm}^{-1}$ were assigned to the bonding of $\mathrm{M}$ (II) with $\mathrm{N}-\mathrm{H}$ and $\mathrm{C}-\mathrm{O}$. Another band due to $\mathrm{C}-\mathrm{O}$ stretching was observed at $1224 \mathrm{~cm}^{-1}$ in the spectra of the precursors. The low-frequency absorptions at 498 and $877 \mathrm{~cm}^{-1}$ were attributed to the $\mathrm{M}-\mathrm{O}$ stretching and $\mathrm{M}-\mathrm{O}$ bending vibrations in the spectra of the complexes. ${ }^{17}$ The $\left[\mathrm{Co}(\mathrm{II})\right.$ benzaldehyde $\cdot$ piperazine $\left.\cdot \mathrm{H}_{2} \mathrm{O}\right]$ $0.5 \mathrm{H}_{2} \mathrm{O}$ was homogenized by ultrasonication. The powder was thoroughly washed with anhydrous ethanol to remove impurities. The compound was dried in an air oven at $60{ }^{\circ} \mathrm{C}$ for $12 \mathrm{~h}$ and then calcinated at $500-600{ }^{\circ} \mathrm{C}$ for $6 \mathrm{~h}$ in an electric furnace. $\mathrm{Co}_{3} \mathrm{O}_{4}$ nanoparticles were prepared with $0.75 \mathrm{~g}$ of the complex [Co(II) benzaldehyde piperazine $\cdot \mathrm{H}_{2} \mathrm{O}$ ] in a porcelain crucible and placed in the furnace. The compound was heated to $500{ }^{\circ} \mathrm{C}$ at a rate of $10{ }^{\circ} \mathrm{C} \mathrm{min}^{-1}$. The cobalt nanoparticles were characterized by various spectroscopic methods. The heterometallic nanocomposite was formed by mixing of [Co(II)benzaldehyde - piperazine $\cdot \mathrm{H}_{2} \mathrm{O}$ ] $0.5 \mathrm{H}_{2} \mathrm{O}$ and [ $\mathrm{Zn}$ (II)benzaldehyde piperazine $\cdot \mathrm{H}_{2} \mathrm{O}$ ], coordination compounds at a $1: 5$ ratio. The high concentration of the zinc coordination compound in methanol was used because $\mathrm{Zn}$ forms a porous material; hence, pockets of $\mathrm{Co}_{3} \mathrm{O}_{4}$ will be formed, which will increase the surface area in the $\mathrm{ZnO} \cdot \mathrm{Co}_{3} \mathrm{O}_{4}$ composite material. The mixture was sonicated for approximately 25 minutes in methanol, filtered, washed with hexane and dried in an oven at $60{ }^{\circ} \mathrm{C}$. The nanoconjugate was prepared by calcination, as reported for homometallic $\mathrm{Co}_{3} \mathrm{O}_{4}$.

\subsection{Computational method}

We carried out a series of theoretical calculations of $\mathrm{ZnO} \cdot \mathrm{Co}_{3} \mathrm{O}_{4}$ molecular aggregates in order to find out how closely they could

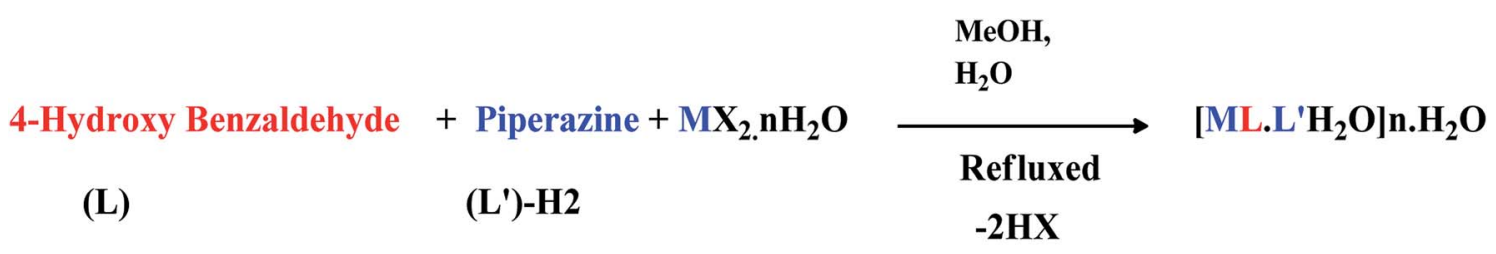

Where $\mathrm{M}=\mathrm{Co}(\mathrm{II}) / \mathrm{Zn}(\mathrm{II}), \mathrm{X}=\mathrm{Cl} / \mathrm{NO}_{3}$, and $\mathrm{n}=0 / 0.5$

Scheme 1 Synthetic route of homo and heterometallic nano particles. 
approach each other and which atoms and their interactions would be involved in the adduct formation. Herein we adopt a three step molecular modeling protocol, (1) generation of $\mathrm{Co}_{3} \mathrm{O}_{4}$ and $\mathrm{ZnO}$ nano particles molecular coordinates from the $\mathrm{X}$-ray crystal structures in two different sizes e.g. $\left[\mathrm{Co}_{3} \mathrm{O}_{4}\right]_{4}(9.00$ $\mathrm{nm}),\left[\mathrm{Co}_{3} \mathrm{O}_{4}\right]_{10}(12 \mathrm{~nm}),[\mathrm{ZnO}]_{4}(5 \mathrm{~nm})$, and $[\mathrm{ZnO}]_{20}(10 \mathrm{~nm}) .(2)$ Geometry optimization of $\left[\mathrm{Co}_{3} \mathrm{O}_{4}\right]_{n}, n=4,10$ with $[\mathrm{ZnO}]_{n}, n=4$, 20, by employing molecular mechanics force field which includes van der Waals (Lennard-Jones potential), hydrogen bonding, desolvation and electrostatic terms and treats the intramolecular bonds and bond angles of both the molecules as rigid. (3) DFT calculation of three geometrically optimized $\left[\mathrm{Co}_{3} \mathrm{O}_{4}\right]_{n} \cdot[\mathrm{ZnO}]_{m}$ adducts (where $n: 4,10$ and $m: 4,20$ ), (a) $\left[\mathrm{Co}_{3} \mathrm{O}_{4}\right]_{4}[\mathrm{ZnO}]_{4},(\mathrm{~b})\left[\mathrm{Co}_{3} \mathrm{O}_{4}\right]_{10}[\mathrm{ZnO}]_{4}$, and (c) $\left[\mathrm{Co}_{3} \mathrm{O}_{4}\right]_{10}[\mathrm{ZnO}]_{20}$. All the molecular mechanic energy-minimization of corresponding molecular adducts were done using Autodock 4.2 software. ${ }^{18}$ All reported DFT computations were performed using ORCA computational package ${ }^{19}$ for previously optimized structures. The single point energy calculation carried out by unrestricted B3LYP functional ${ }^{20}$ using Aldrich's def2-TZVP basis set for all the atoms ${ }^{21}$ to calculate the HOMO and LUMO energies. To speed up the calculations we have used the resolution of identity (RI) approximation with the decontracted auxiliary def2-TZV/J Coulomb fitting basis sets and the chain-ofspheres (RIJCOSX) approximation to exact exchange as executed in ORCA. DFT calculation utilizes the atom-pairwise dispersion correction with the Becke-Johnson damping scheme (D3BJ). ${ }^{22}$

\section{Results and discussion}

The precursors of homo- and heterometallic nano oxides were prepared by using the coordination chemistry concept with a lowcost starting material. The characterization and morphology of the nano $\mathrm{Co}_{3} \mathrm{O}_{4}$ and $\mathrm{ZnO} \cdot \mathrm{Co}_{3} \mathrm{O}_{4}$ were studied by TEM and SEM images. The TEM images showed that $\mathrm{Co}_{3} \mathrm{O}_{4}$ and $\mathrm{ZnO} \cdot \mathrm{Co}_{3} \mathrm{O}_{4}$ particles possessed a rectangular unit cell with several vertices of $\mathrm{Co}_{3} \mathrm{O}_{4}$ (size 19.14-56.20 $\mathrm{nm}$ ) and porous $\mathrm{ZnO}$ crystalline (22.79 nm pore size) pockets filled with $\mathrm{Co}_{3} \mathrm{O}_{4}$. The particle size of the rectangular pyramidal units was $14.14-16.13 \mathrm{~nm}$. On the basis of the TEM images, it can be concluded that particle overlap occurred and that different long nanoconjugates were obtained by interfacial reactions and agglomeration. The SEM results
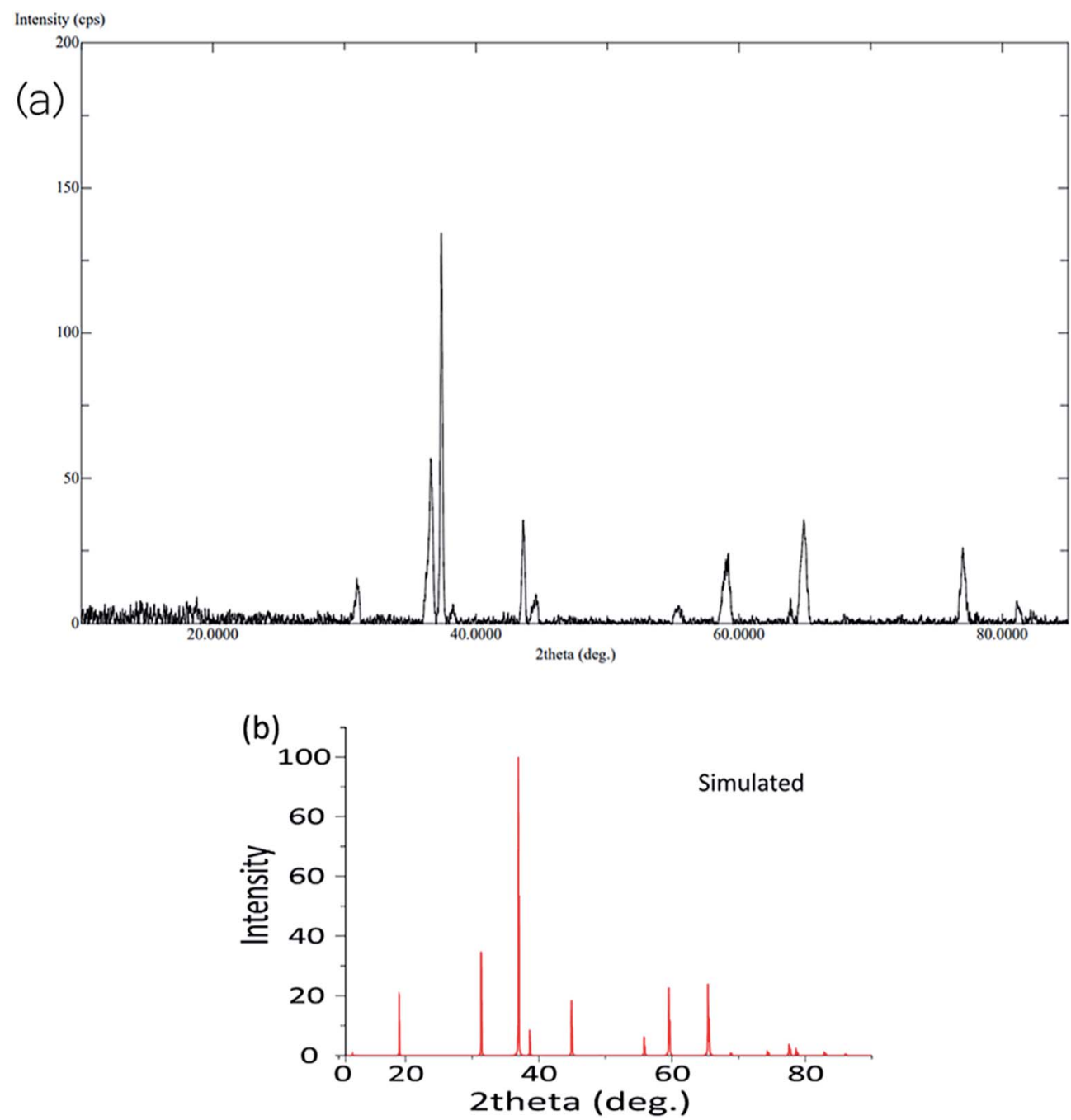

Fig. 1 Experimental and simulated XRD pattern of $\mathrm{CO}_{3} \mathrm{O}_{4}$ nanoparticles. 


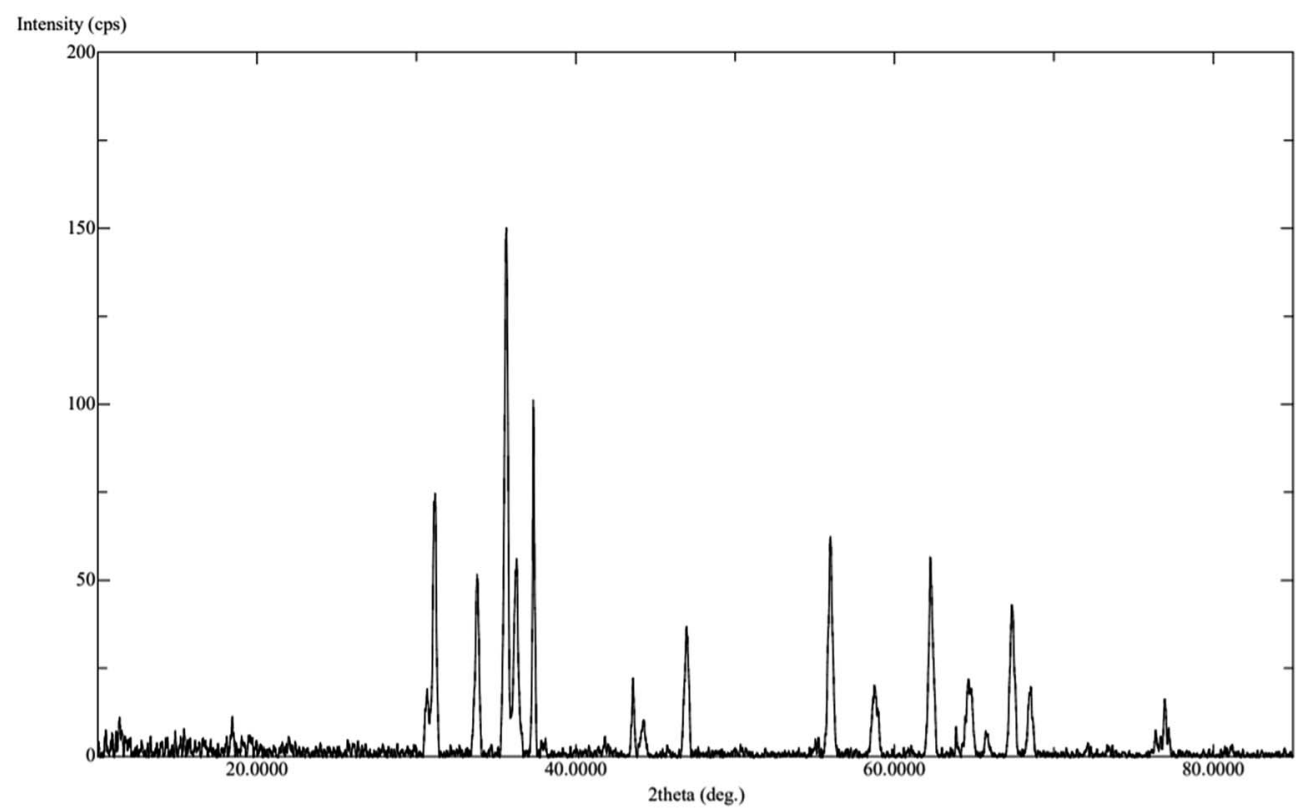

Fig. 2 XRD pattern of $\mathrm{ZnO} \cdot \mathrm{CO}_{3} \mathrm{O}_{4}$ nanoparticles.

corroborated well with the TEM results for the $\mathrm{Co}_{3} \mathrm{O}_{4}$ and $\mathrm{ZnO} \cdot \mathrm{Co}_{3} \mathrm{O}_{4}$ nanoparticles. This procedure is important because we can obtain identical nano oxide particles with a defined geometry by repeating the procedure.

\subsection{Infrared spectroscopy}

FTIR spectra were recorded for cobalt and zinc nanoparticles to confirm the bonding of oxides to metal ions in the nanocrystal materials and the cationic position in the structure. The FTIR spectra (Fig. S1 and S2 $\dagger$ ) showed two characteristic stretching vibrations bands of the $\mathrm{M}-\mathrm{O}$ bonds in $\mathrm{Co}_{3} \mathrm{O}_{4}$. A sharp band appeared at $583 \mathrm{~cm}^{-1}$ due to the vibration of $\mathrm{Co}$ (III) ions in the octahedral void of oxide ions. The second band appeared at $665 \mathrm{~cm}^{-1}$, confirming the presence of $\mathrm{Co}^{2+}$ in the tetrahedral hole, which resulted in the formation of pure nanocrystals..$^{23} \mathrm{~A}$ similar FTIR was obtained for $\mathrm{ZnO} \cdot \mathrm{Co}_{3} \mathrm{O}_{4}$, with additional weak bands at a lower frequency of $580 \mathrm{~cm}^{-1}$, which indicated the

\section{JED-2200 Series}

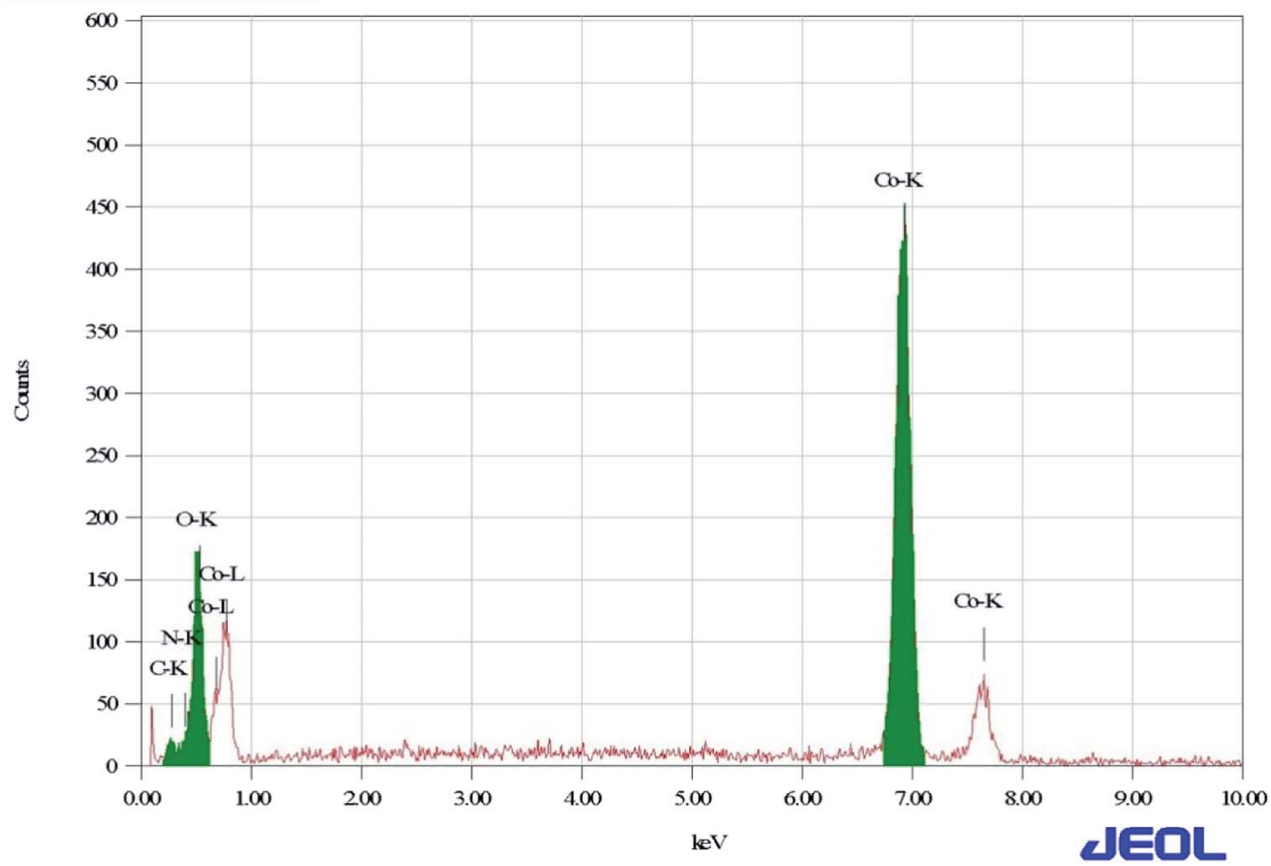

Fig. 3 EDX of $\mathrm{CO}_{3} \mathrm{O}_{4}$ 


\section{$\underline{J E D-2200 ~ S e r i e s}$}

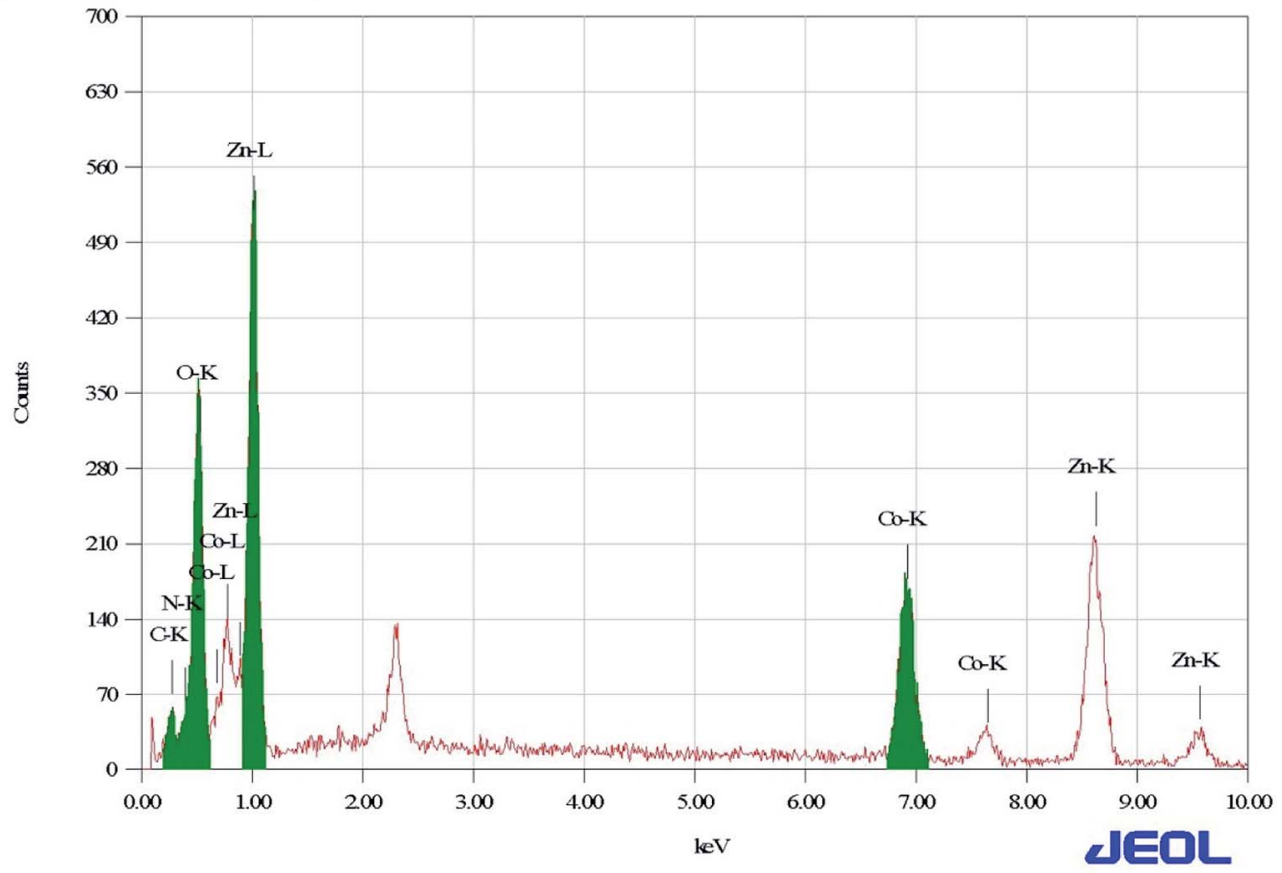

Fig. $4 \mathrm{EDX}$ of $\mathrm{ZnO} \cdot \mathrm{CO}_{3} \mathrm{O}_{4}$.

(a)

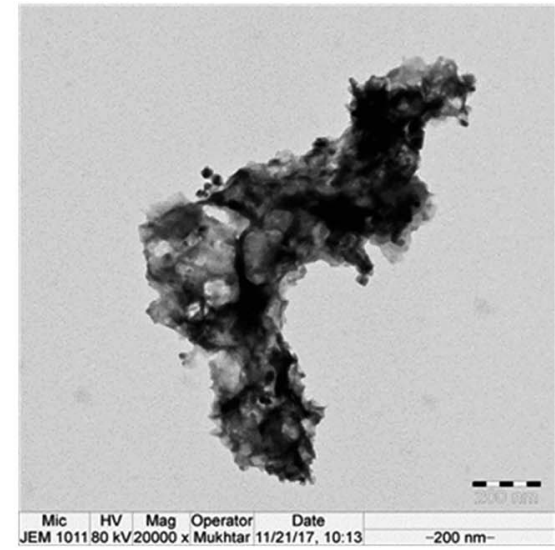

(c)

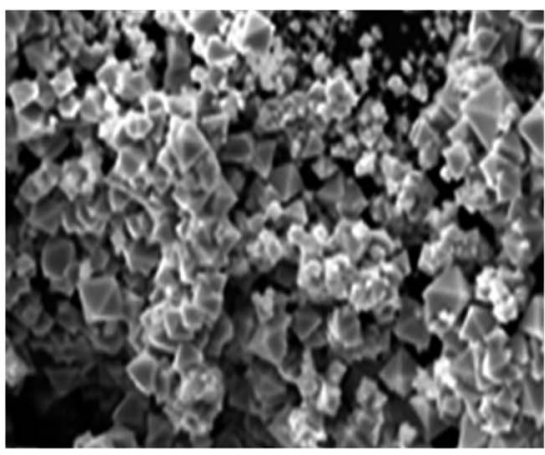

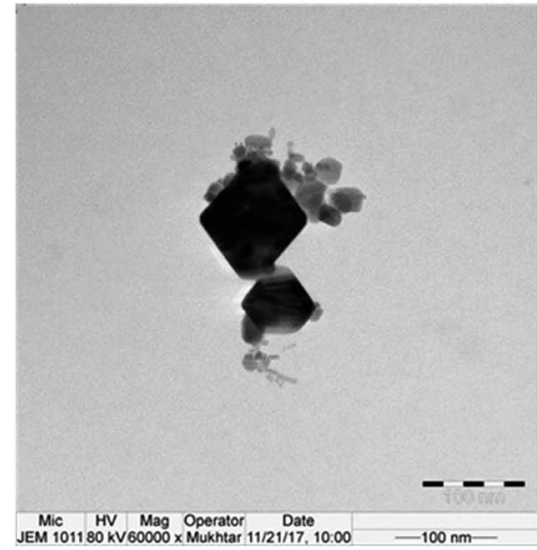

(b)

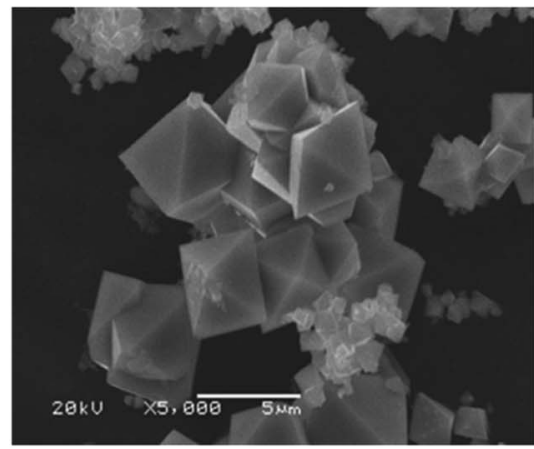

(d)

Fig. 5 Typical TEM images: (a) $\mathrm{CO}_{3} \mathrm{O}_{4}$ nanoparticles and (b) the shape and size of the particles. Typical SEM images of a $\mathrm{CO}_{3} \mathrm{O}_{4}$ (c) bulk particle and (d) the geometry of $\mathrm{CO}_{3} \mathrm{O}_{4}$ particles. 
presence of $\mathrm{Zn}$ oxide with $\mathrm{Co}_{3} \mathrm{O}_{4} \cdot{ }^{24}$ The cobalt was present as $\mathrm{Co}^{2+}$, and two cobalt ions were in the $\mathrm{Co}^{3+}$ oxidation state. Mixed oxidation states (divalent and trivalent ions) provide crystal field stabilization at the octahedral $\left(\mathrm{Co}^{3+}\right)$ and tetrahedral $\left(\mathrm{Co}^{2+}\right)$ sites of $\mathrm{Co}_{3} \mathrm{O}_{4}$. No other band was observed, thus confirming the purity of the oxide nanoparticles.

\subsection{Thermo gravimetric analysis (TGA)}

The TGA analysis of the [M(II)benzaldehyde piperazine $\cdot \mathrm{H}_{2} \mathrm{O}$ ] $n \mathrm{H}_{2} \mathrm{O}$, with $\mathrm{M}=\mathrm{Co}$ (II)/Zn(II), indicated a double-step weight loss between $573-763 \mathrm{~K}$. The weight loss indicated the decomposition of [M(II)benzaldehyde piperazine $\left.\cdot \mathrm{H}_{2} \mathrm{O}\right]$ into the metal oxides $\mathrm{Co}_{3} \mathrm{O}_{4} / \mathrm{ZnO}$. The weight loss was found to be approximately $68 \%$, which is equivalent to the loss of water, aldehyde and piperazine compounds to form cobalt oxide/zinc oxide. The observed weight loss of cobalt oxide was close to the theoretical value. Upon the calcination of the obtained [Co(II)benzaldehyde $\cdot$ piperazine $\cdot \mathrm{H}_{2} \mathrm{O}$ ] $n \mathrm{H}_{2} \mathrm{O}$ and the mixture of [Co(II)benzaldehyde $\cdot$ piperazine $\cdot \mathrm{H}_{2} \mathrm{O}$ ] $n \mathrm{H}_{2} \mathrm{O}$, [Zn(II)benzaldehyde $\cdot$ piperazine $\cdot \mathrm{H}_{2} \mathrm{O}$ ] at $773 \mathrm{~K}$ in air, both metal complexes were converted into $\mathrm{Co}_{3} \mathrm{O}_{4}$ and $\mathrm{ZnO} \cdot \mathrm{Co}_{3} \mathrm{O}_{4}$ nanoparticles. The TGA (Fig. S3 $\dagger$ ) curves of the $\mathrm{Co}_{3} \mathrm{O}_{4}$ oxide nanoparticles show no weight loss, indicating the purity and stability of the particles. The XRD pattern of the sample also clearly indicated that nano $\mathrm{Co}_{3} \mathrm{O}_{4}$ particles are pure oxides.

\subsection{XRD measurement}

The calcination process was performed directly at $500-600{ }^{\circ} \mathrm{C}$ to convert the mono metallic compound and mixture of two

\section{(a)}

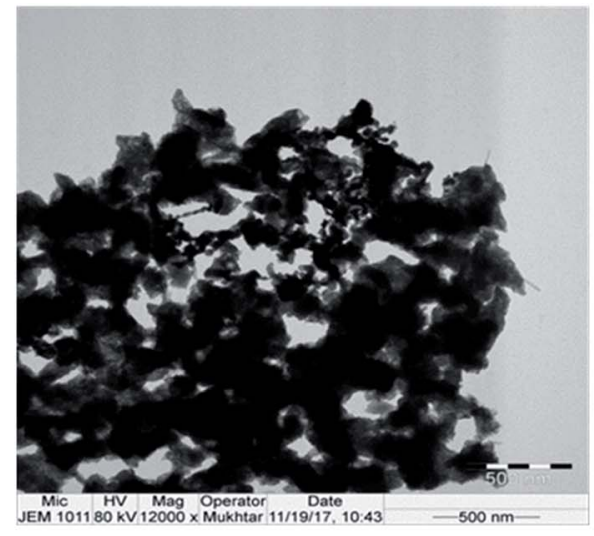

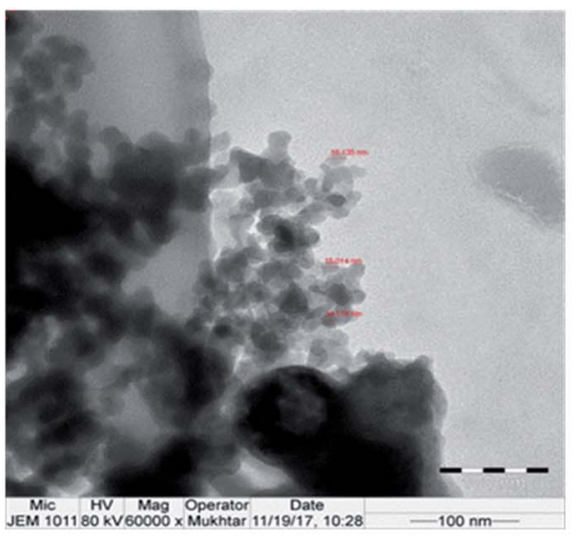

(b)

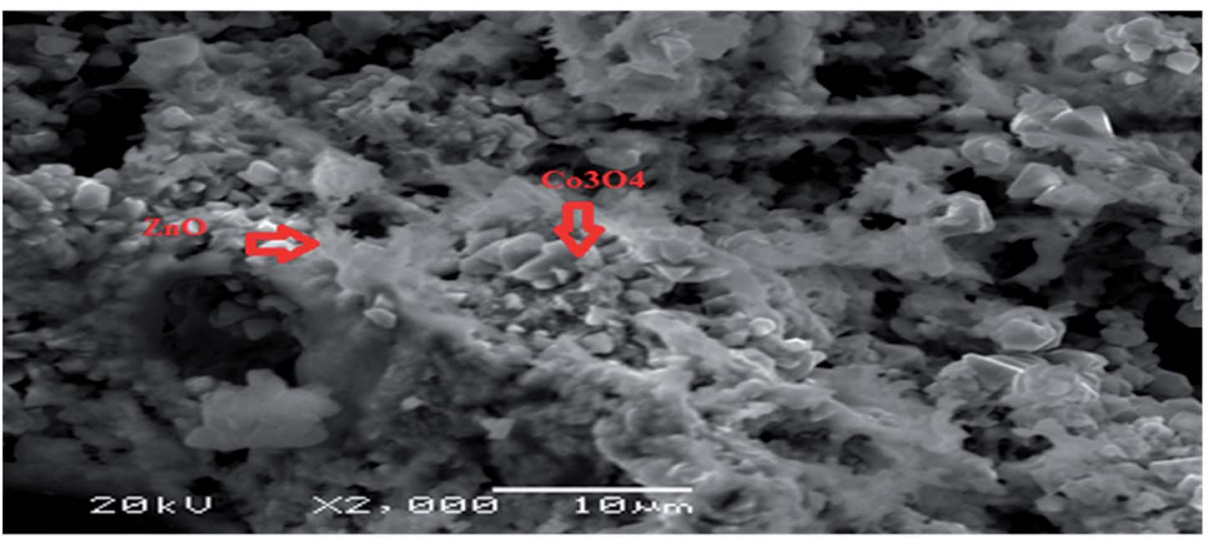

(c)

(d)
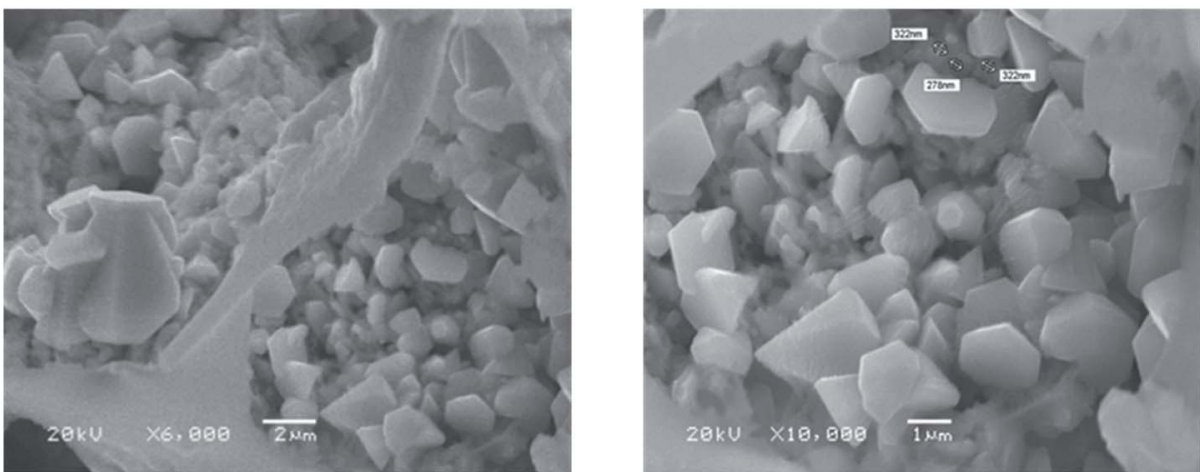

(e)

Fig. 6 Typical TEM images, (a) and (b) of the structure and size of $\mathrm{ZnO} \cdot \mathrm{Co}_{3} \mathrm{O}_{4}$ particles. SEM images of $\mathrm{ZnO} \cdot \mathrm{Co}_{3} \mathrm{O}_{4}$, showing (c) the porous structure of $\mathrm{ZnO}$ with, (d) and (e), pockets of $\mathrm{CO}_{3} \mathrm{O}$. 


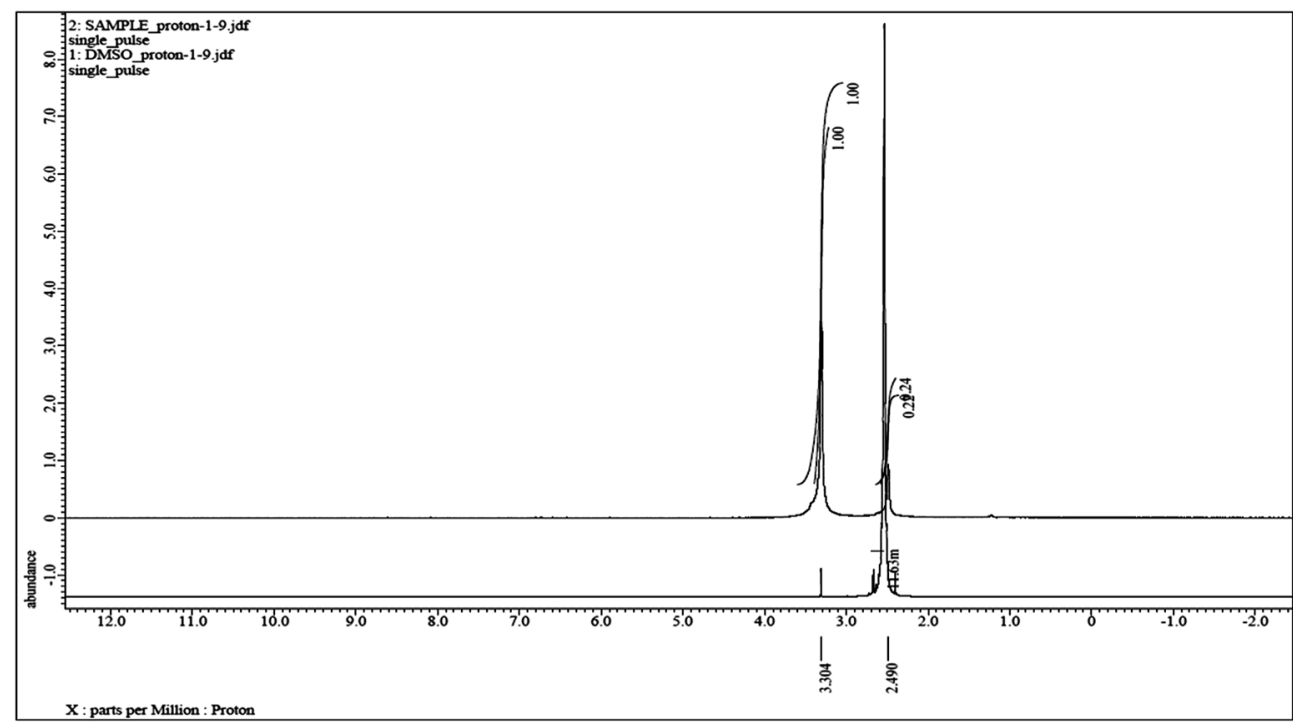

Fig. $7{ }^{1} \mathrm{H}$ NMR chemical shift due to $\mathrm{CO}_{3} \mathrm{O}_{4}$.

complexes to get homo and heterometallic oxides. The nano $\mathrm{Co}_{3} \mathrm{O}_{4}$ and $\mathrm{ZnO} \cdot \mathrm{Co}_{3} \mathrm{O}_{4}$ products maintained the crystalline phases of the oxides over time (Fig. S4 $\uparrow$ ). The X-ray diffraction confirmed that both the nano $\mathrm{Co}_{3} \mathrm{O}_{4}$ and $\mathrm{ZnO} \cdot \mathrm{Co}_{3} \mathrm{O}_{4}$ composite were pure. The peaks of the $\mathrm{Co}_{3} \mathrm{O}_{4}$ and $\mathrm{ZnO} \cdot \mathrm{Co}_{3} \mathrm{O}_{4}$ were observed at $2 \theta=36.56^{\circ}, 37.56^{\circ}, 38.24^{\circ}, 43.58^{\circ}, 64.92^{\circ}$, and $65.04^{\circ}$ due to the $111,220,311,400,440$ and 511 planes for $\mathrm{Co}_{3} \mathrm{O}_{4}$. For $\mathrm{ZnO} \cdot \mathrm{Co}_{3} \mathrm{O}_{4}$, peaks were observed at $2 \theta=30.50^{\circ}$, $31.20^{\circ}, 31.35^{\circ}, 33.78^{\circ}, 35.56^{\circ}, 36.30^{\circ}, 36.56^{\circ}, 37.34^{\circ}, 37.56^{\circ}$, $43.58^{\circ}, 46.96^{\circ}, 55.96^{\circ}, 62.24^{\circ}$, and $64.92^{\circ}$, due to $\mathrm{ZnO} 100,002$, $101,102,110$ and 103 . Hexagonal $\mathrm{ZnO}$ with a lattice along the $\mathrm{Co}_{3} \mathrm{O}_{4}$ diffraction lines 111, 220, 313, 400, 422, 440, and 511 corresponded to a rectangular pyramidal crystal supported by JCPDS data (Fig. 1). Our results are in good agreement with previously reported results. ${ }^{24}$ No peaks signifying other combinations of cobalt were obtained, which confirms the purity and crystalline structure of the $\mathrm{Co}_{3} \mathrm{O}_{4}$ nanoparticle and $\mathrm{ZnO} \cdot \mathrm{Co}_{3} \mathrm{O}_{4}$. Additionally, the simulated XRD pattern of $\mathrm{Co}_{3} \mathrm{O}_{4}$ structure is in good agreement with the experimentally observed XRD pattern also indicated the purity of $\mathrm{Co}_{3} \mathrm{O}_{4}$ nanoparticles (Fig. 2). The size $(\sim 15-31 \mathrm{~nm})$ of the crystalline phase $\mathrm{Co}_{3} \mathrm{O}_{4}$ nanocrystal and the $\mathrm{Zn}$ porous crystal containing $\mathrm{Co}_{3} \mathrm{O}_{4}$ was calculated from the XRD data using the Scherrer equation (a).$^{25}$ The similar range of the size of the particle was measured by TEM, which supports the stable phase of the crystalline material at room temperature after calcination.

\subsection{EDX analysis}

The $\mathrm{Co}_{3} \mathrm{O}_{4}$ and mixed oxide $\mathrm{Zno} \cdot \mathrm{Co}_{3} \mathrm{O}_{4}$ nanoparticles prepared by calcination of the $\left[\mathrm{Co} / \mathrm{Zn}(\mathrm{II})\right.$ benzaldehyde $\cdot$ piperazine $\cdot \mathrm{H}_{2} \mathrm{O}$ ] complex at $500{ }^{\circ} \mathrm{C}$ were characterized by EDX, SEM and TEM. The analysis data supported the formation of one type of aggregated nanoparticles with an average size of $15-31 \mathrm{~nm}$. The rectangular pyramidal morphology and size of the particles were further calculated by the XRD spectrum to validate the
TEM results. Polycrystalline $\mathrm{Co}_{3} \mathrm{O}_{4}$ and porous $\mathrm{ZnO} \cdot \mathrm{Co}_{3} \mathrm{O}_{4}$ particles were analysed by energy-dispersive X-ray (EDX) spectra of $\mathrm{Co}_{3} \mathrm{O}_{4}$ (Fig. 3) and mixed $\mathrm{ZnO} \cdot \mathrm{Co}_{3} \mathrm{O}_{4}$ (Fig. 4). In the spectra, Co and $\mathrm{O}$ peaks were detected in both $\mathrm{Co}_{3} \mathrm{O}_{4}$ and $\mathrm{ZnO} \cdot \mathrm{Co}_{3} \mathrm{O}_{4}$, and $\mathrm{Zn}$ peaks were observed in the $\mathrm{ZnO} \cdot \mathrm{Co}_{3} \mathrm{O}_{4}$ spectra. This reveals that cobalt oxide aligned with $\mathrm{ZnO}$ to yield the composite. The EDX spectra of the oxides and element maps obtained showed the composition and mass percentages of $\sim 21 \%$ oxygen and $76 \%$ metals for the elements $\mathrm{O}$, Co, and $\mathrm{Zn}$, respectively. Carbon signals originating from grid background were observed at a negligible percentage.

\subsection{Morphologies of $\mathrm{CoCo}_{3}$ and $\mathrm{ZnO} \cdot \mathrm{Co}_{3} \mathrm{O}_{4}$}

TEM and SEM images of nanomaterials prepared at $500{ }^{\circ} \mathrm{C}$ were obtained. The shape of the particles depends on the chemical environment precipitation and aggregation method. Homo and hetero metal oxides aggregated to minimize the interfacial energy are cubic nanoparticles with an average particle size of 15-31 nm (Fig. 5a-d). The morphology of $\mathrm{Co}_{3} \mathrm{O}_{4}$, with an average diameter of $31.0 \mathrm{~nm}$, in a regular crystalline phase indicated that $\mathrm{CoCo}_{3}$ contains nanocrystals with a single shape. It was observed that the hexagonal crystalline porous $\mathrm{ZnO}$ cavity was uniformly filled with $\mathrm{Co}_{3} \mathrm{O}_{4}$ particles. The magnified SEM images show a uniform morphology (Fig. 6a-c). Porous hetero nanocrystals are important for electrochemical studies. To confirm the effect that the nature of the porous $\mathrm{ZnO}$ has on $\mathrm{Co}_{3} \mathrm{O}_{4}$ deposition, comparative cyclic voltammetry experiments were performed.

Transmission electron microscopy (TEM) images of the homo and heteronano structure of $\mathrm{Co}_{3} \mathrm{O}_{4}$ and $\mathrm{ZnO} \cdot \mathrm{Co}_{3} \mathrm{O}_{4}$ (Fig. 5 and 6a, b) show low-magnification images of $\mathrm{Co}_{3} \mathrm{O}_{4}$ and mixed $\mathrm{ZnO} \cdot \mathrm{Co}_{3} \mathrm{O}_{4}$. The magnified images of $\mathrm{Co}_{3} \mathrm{O}_{4}$ exhibited a rectangular pyramidal type, as shown in Fig. 9a, with directional edges. The clear shape of the crystals was studied by SEM. The $\mathrm{ZnO} \cdot \mathrm{Co}_{3} \mathrm{O}_{4}$ material was scanned by TEM, and it was 

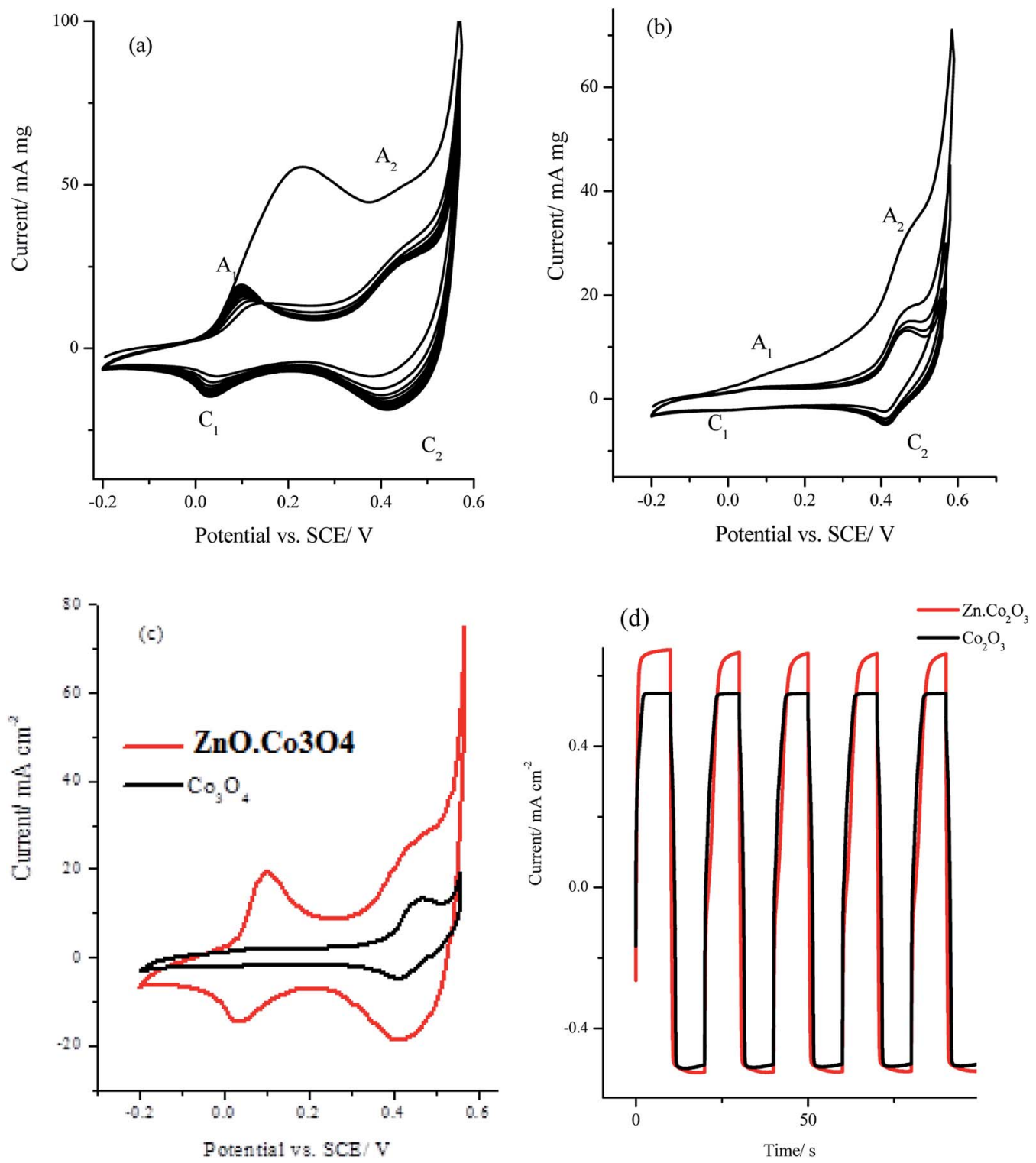

Fig. 8 Multi-cyclic voltammetry at $50 \mathrm{mV} \mathrm{s}^{-1}$ in $1.0 \mathrm{M} \mathrm{KOH}$ for (a) for $\mathrm{ZnO} \cdot \mathrm{CO}_{3} \mathrm{O}_{4}$, (b) $\mathrm{Co}_{3} \mathrm{O}_{4}$ nanocrystals and (c) comparison for the stable cycle, (d) galvanostatic charge-discharge curves of $\mathrm{ZnO} \cdot \mathrm{CO}_{3} \mathrm{O}_{4}$ and $\mathrm{CO}_{3} \mathrm{O}_{4}$ electrodes at charge current of $4.0 \mathrm{~A} \mathrm{~g}^{-1}$.

observed that the hetero nanostructure is a porous conjugate of mixed oxide. Fig. 10a and b also reveal nanopolycrystalline $\mathrm{Co}_{3} \mathrm{O}_{4}$ deposited in the single crystalline $\mathrm{ZnO}$ porous cavities. The TEM observation was further validated by SEM analysis (Fig. $6 \mathrm{c}$ and d). ${ }^{26}$

\subsection{Paramagnetic character evaluation of nanoparticle $\mathrm{Co}_{3} \mathrm{O}_{4}$}

NMR was employed to study the paramagnetic character of metal in nanophases in solution. The ${ }^{1} \mathrm{H}$ NMR chemical shift due to $\mathrm{Co}_{3} \mathrm{O}_{4}$ was monitored by Evan's method. Evan's NMR studies $^{27,28}$ showed a paramagnetic chemical shift of $\sim 0.8 \mathrm{ppm}$ in the DMSO dimethyl proton signal at $2.49 \mathrm{ppm}$. The sharp change in the chemical shift at $3.3 \mathrm{ppm}$ in the NMR spectrum clearly indicated that the particle exhibits paramagnetism
(Fig. 7). The small shift in the NMR signals indicates that $\mathrm{Co}_{3} \mathrm{O}_{4}$ nanoparticles have weak ferromagnetic behaviour.

\subsection{Electrochemistry}

The cyclic voltammetry (CV) measurements for $\mathrm{Co}_{3} \mathrm{O}_{4}$ and $\mathrm{ZnO} \cdot \mathrm{Co}_{3} \mathrm{O}_{4}$ nanocrystals in $1.0 \mathrm{M} \mathrm{KOH}$ at a scan rate of $50 \mathrm{mV}$ $\mathrm{S}^{-1}$ are depicted in Fig. 8. The cyclic voltammograms of the nanocrystals of $\mathrm{Co}_{3} \mathrm{O}_{4}$ and $\mathrm{ZnO} \cdot \mathrm{Co}_{3} \mathrm{O}_{4}$ (Fig. 8a and b) exhibited two redox peaks of $\left(\mathrm{A}_{1} / \mathrm{C}_{1}\right)$ and $\left(\mathrm{A}_{2} / \mathrm{C}_{2}\right)$ that could be attributed to the redox couples $\mathrm{Co}(\mathrm{II}) / \mathrm{Co}(\mathrm{III})$ and $\mathrm{Co}(\mathrm{III}) / \mathrm{Co}(\mathrm{IV})$ and are located at the mid-peak potential of 65 and $430 \mathrm{mV} v s$. SCE, respectively. ${ }^{29}$ However, for the hetero-bimetallic nano oxide $\mathrm{ZnO} \cdot \mathrm{Co}_{3} \mathrm{O}_{4}$, the redox peaks were well resolved and had a significantly higher current than did the $\mathrm{Co}_{3} \mathrm{O}_{4}$ electrode as shown in Fig. 8c. Moreover, the oxidation current during the 

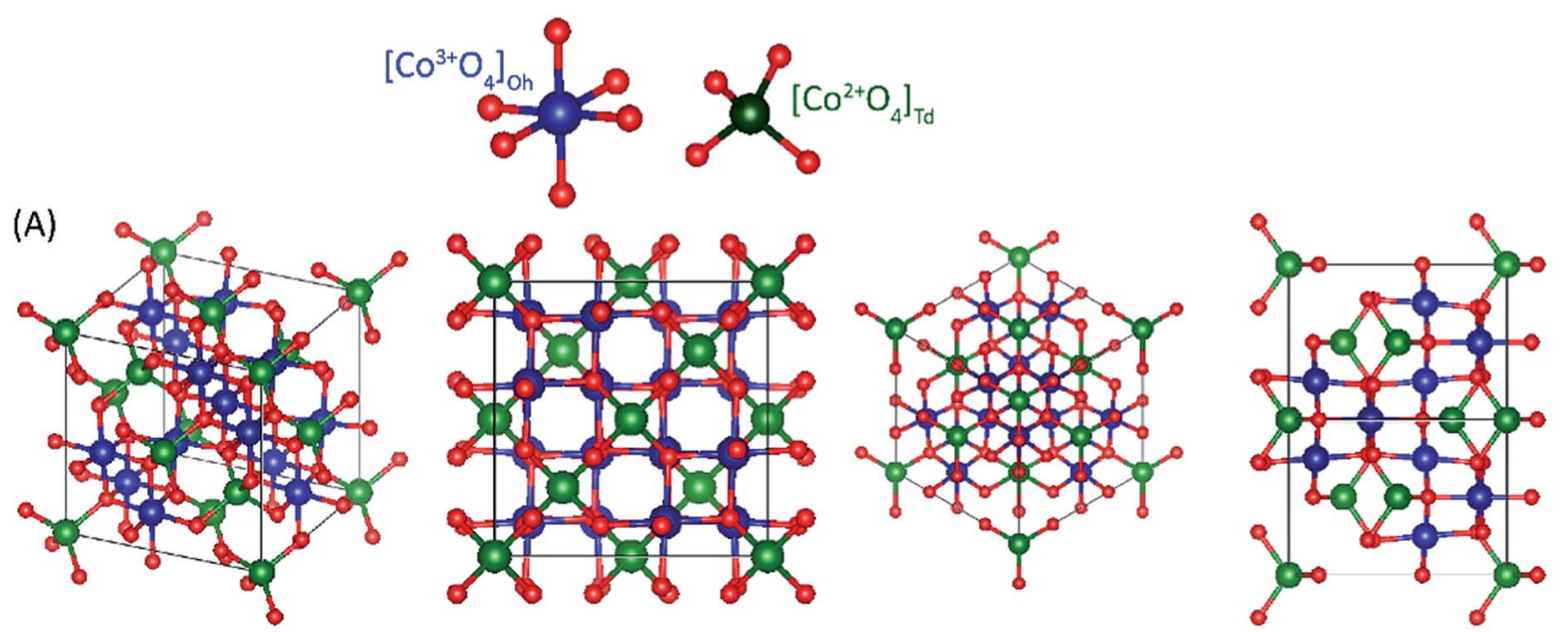

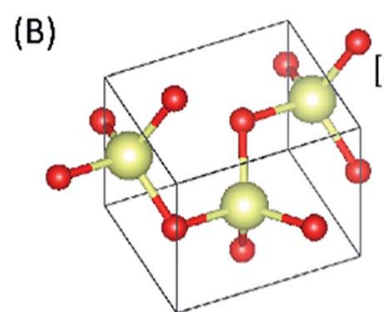

$\{112\}$

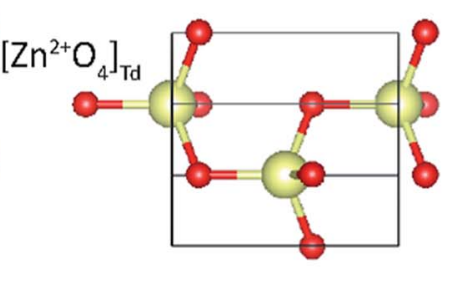

$\{100\}$

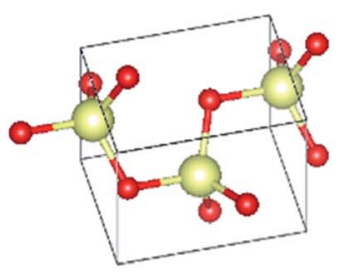

$\{111\}$

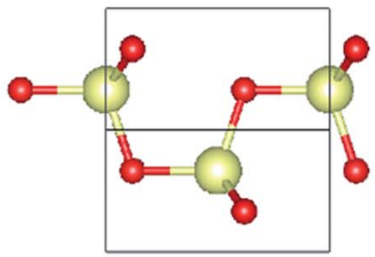

$\{110\}$

Fig. 9 The illustration of atom configurations of the $\{100\},\{110\},\{111\}$, and $\{112\}$ crystal planes of the $\mathrm{CO}_{3} \mathrm{O}_{4}$ spinel and $\mathrm{ZnO}$ structure.

first anodic scan was much higher before it stabilized in the successive scans for both oxides, apparently due to a complete conversion of the $\mathrm{ZnO} \cdot \mathrm{Co}_{3} \mathrm{O}_{4}$ and $\mathrm{Co}_{3} \mathrm{O}_{4}$ to higher oxidized species, which was not completely reversible in the alkaline solution. ${ }^{30-32}$ The specific capacitance of the $\mathrm{ZnO} \cdot \mathrm{Co}_{3} \mathrm{O}_{4}$ and $\mathrm{Co}_{3} \mathrm{O}_{4}$ electrodes can be calculated from the $\mathrm{CV}$ using eqn (1):

$$
C_{\mathrm{s}}=Q / 2 m \Delta V
$$

where $C_{\mathrm{s}}$ is the specific capacitance in $\left(\mathrm{F} \mathrm{g}^{-1}\right), Q$ is the volumetric charge under the $\mathrm{CV}$ in coulomb, $m$ is the mass of the oxide materials in grams and $\Delta V$ is the potential window of the cyclic voltammetry. Using the cyclic voltammetry in Fig. 8c, the specific capacitance values were estimated to be 207.3 and 51.1 $\mathrm{F} \mathrm{g}^{-1}$ for $\mathrm{ZnO} \cdot \mathrm{Co}_{3} \mathrm{O}_{4}$ and $\mathrm{Co}_{3} \mathrm{O}_{4}$ electrodes, respectively. Moreover, Fig. $8 \mathrm{~d}$ illustrates the galvanostatic charge-discharge curves of $\mathrm{ZnO} \cdot \mathrm{Co}_{3} \mathrm{O}_{4}$ and $\mathrm{Co}_{3} \mathrm{O}_{4}$ electrodes at charge current of $4.0 \mathrm{~A} \mathrm{~g}^{-1}$ and in $1.0 \mathrm{M} \mathrm{KOH}$ solution. The specific capacitance obtained from each discharge curve is equal 210.5 and $54.6 \mathrm{~F}$ $\mathrm{g}^{-1}$ for $\mathrm{ZnO} \cdot \mathrm{Co}_{3} \mathrm{O}_{4}$ and $\mathrm{Co}_{3} \mathrm{O}_{4}$ electrodes respectively which is in good agreement with the values obtained from the cyclic voltammetry. These observations indicate that heterometallic $\mathrm{ZnO} \cdot \mathrm{Co}_{3} \mathrm{O}_{4}$ exhibited a much higher specific capacitance than did a monometallic $\mathrm{Co}_{3} \mathrm{O}_{4}$ nanocrystal, which could be attributed presumably to the mesoporous structure and higher surface area that allow fast ion diffusion and better conductivity as a result of $\mathrm{ZnO}$ incorporation into the $\mathrm{Co}_{3} \mathrm{O}_{4}$ structure. ${ }^{33}$

\subsection{Computational modelling}

Ambient chemical transformations between nanoparticles of $\mathrm{Co}_{3} \mathrm{O}_{4}$ and $\mathrm{ZnO}$ leading to hybrid molecular adducts that preserve structure and topology are poorly explored area in material science. Atomically precise nanoparticles of Co and $\mathrm{Zn}$ metals, often called nanoclusters, which constitute an exploding discipline in nanomaterials because of their well-defined structures and drastic changes in their properties, in comparison to their bulk form, arising due to electronic confinement. Hence, theoretical calculations of $\mathrm{ZnO} \cdot \mathrm{Co}_{3} \mathrm{O}_{4}$ molecular aggregates have been performed in order to find out how closely they could approach each other and which atoms and their interactions would be involved in the adduct formation.

A complete search over the relevant rotational and translational degrees of freedom of $\mathrm{Co}_{3} \mathrm{O}_{4}$ nanocluster with respect to $\mathrm{ZnO}$ nanocluster in the $\mathrm{Co}_{3} \mathrm{O}_{4} \mathrm{ZnO}$ adduct with DFT is unfeasible due to the computational cost. Therefore, we used a combined approach utilizing the highly efficient force-field based method to identify a global minimum energy geometry of the $\mathrm{Co}_{3} \mathrm{O}_{4} \mathrm{ZnO}$ adducts, e.g. model 1: $\left[\mathrm{Co}_{3} \mathrm{O}_{4}\right]_{4}[\mathrm{ZnO}]_{4}$, model 2: $\left[\mathrm{Co}_{3} \mathrm{O}_{4}\right]_{10}[\mathrm{ZnO}]_{4}$, and model 3: $\left[\mathrm{Co}_{3} \mathrm{O}_{4}\right]_{10}[\mathrm{ZnO}]_{20}$ and then performed single point energy calculations using DFT method to calculate the electronic properties. We have used the reported crystal structure coordinates of $\mathrm{Co}_{3} \mathrm{O}_{4}$ and $\mathrm{ZnO}$, without any structural relaxation, as the initial coordinates for geometry optimizations. The atom configurations of the $\{100\},\{110\}$, $\{111\}$, and $\{112\}$ crystal planes of the $\mathrm{Co}_{3} \mathrm{O}_{4}$ spinel and $\mathrm{ZnO}$ adducts are depicted in Fig. 9. Similarly, the crystal planes (100, 
(A)
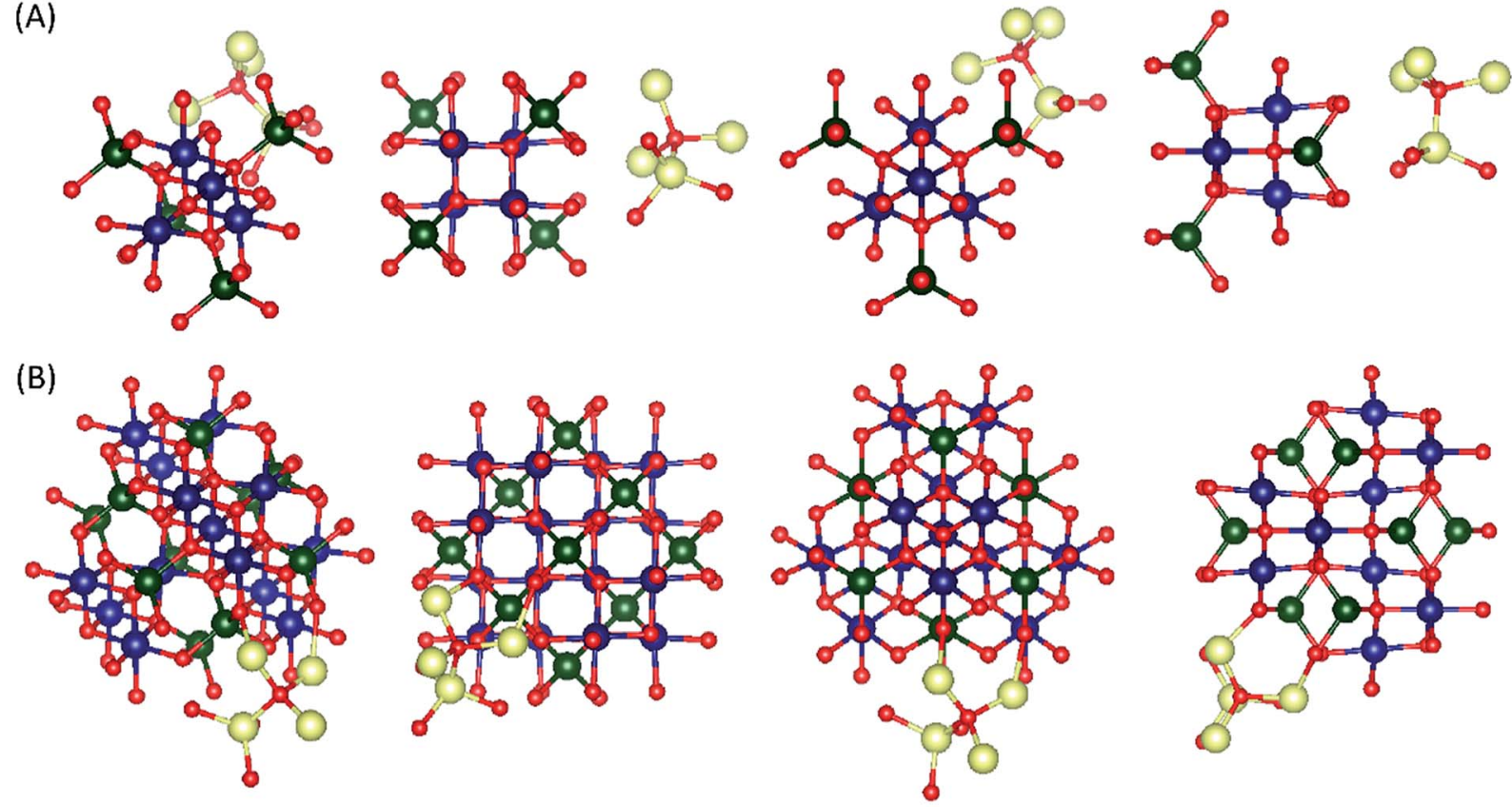

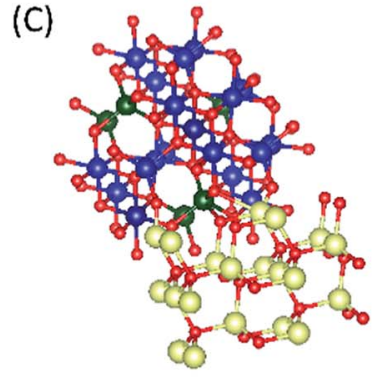

$\{112\}$

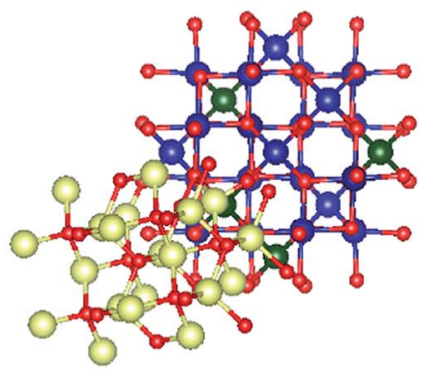

$\{100\}$

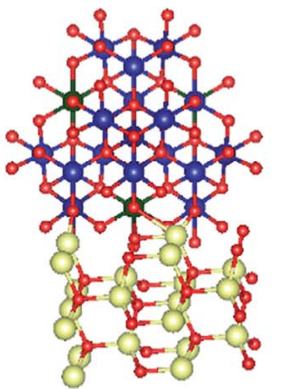

$\{111\}$

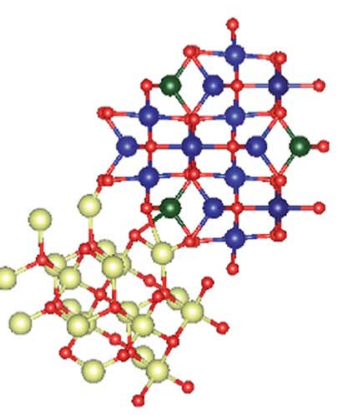

$\{110\}$

Fig. 10 The illustration of atom configurations of the $\{100\},\{110\},\{111\}$, and $\{112\}$ crystal planes of the global minimum energy geometry of $\mathrm{CO}_{3} \mathrm{O}_{4} \mathrm{ZnO}$ adducts, (A) model 1 , (B) model 2, and (C) model 3.

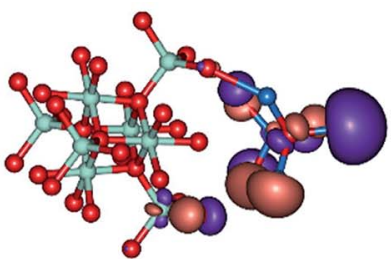

HOMO $(-7.4 \mathrm{eV})$

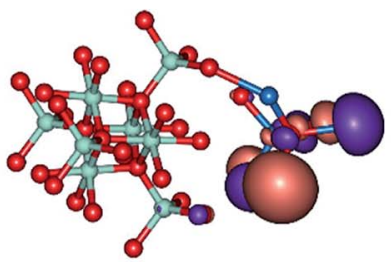

LUMO (-6.24 eV)

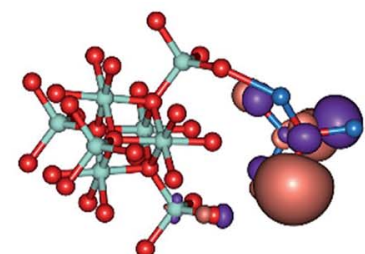

HOMO-1 (-7.61 eV)

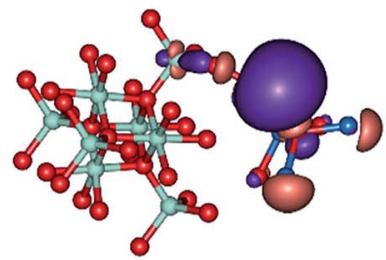

LUMO+1 (-5.87 eV)

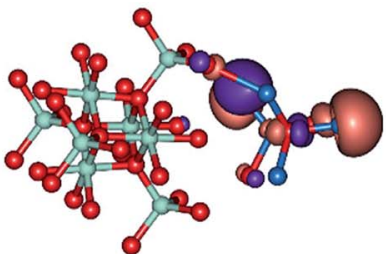

HOMO-2 (-7.71 eV)

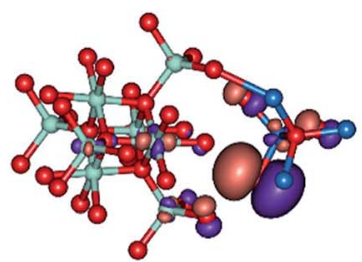

LUMO+2 (-5.09 eV)

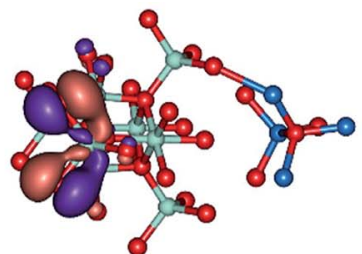

HOMO-3 (-7.80 eV)

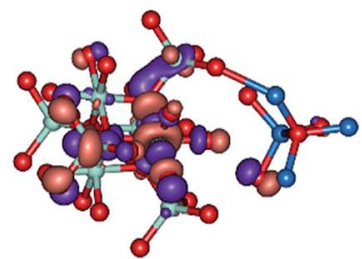

LUMO+3 (-4.96 eV)

Fig. 11 Frontier molecular orbitals and their energies of model 1: $\left[\mathrm{CO}_{3} \mathrm{O}_{4}\right]_{4}[\mathrm{ZnO}]_{4}$ adduct. 


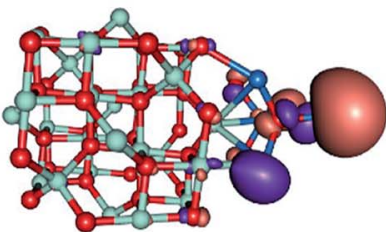

HOMO (-5.90 eV)

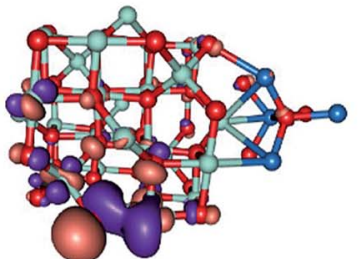

LUMO (-4.34 eV)

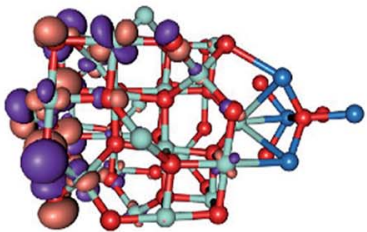

HOMO-1 (-5.97 eV)

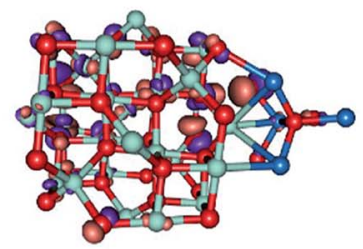

LUMO+1 (-4.27 eV)

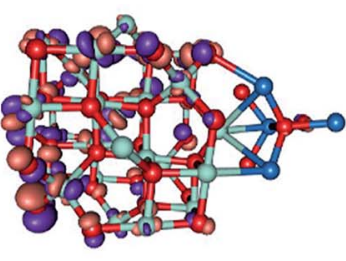

HOMO-2 (-6.10 eV)

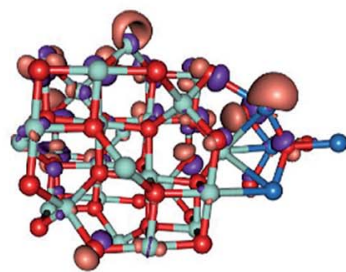

LUMO+2 (-4.17 eV)

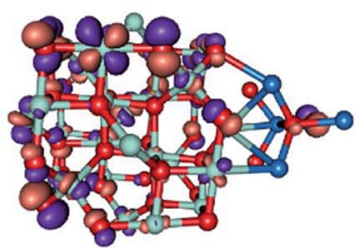

HOMO-3 (-6.11 eV)

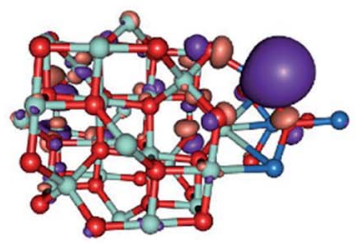

LUMO+3 (-4.02 eV)

Fig. 12 Frontier molecular orbitals and their energies of model 2: $\left[\mathrm{CO}_{3} \mathrm{O}_{4}\right]_{10}[\mathrm{ZnO}]_{4}$ adduct.

110,111 and 112) of the global minimum energy geometries of the three adducts of $\mathrm{Co}_{3} \mathrm{O}_{4}$ and $\mathrm{ZnO}$ e.g. model 1: $\left[\mathrm{Co}_{3} \mathrm{O}_{4}\right]_{4}$ $[\mathrm{ZnO}]_{4}$, model 2: $\left[\mathrm{Co}_{3} \mathrm{O}_{4}\right]_{10}[\mathrm{ZnO}]_{4}$, and model 3: $\left[\mathrm{Co}_{3} \mathrm{O}_{4}\right]_{10}$
$[\mathrm{ZnO}]_{20}$ are illustrated in Fig. 10 and $55 . \dagger$ From the force-field global minimum geometries (FFGMG) of adducts, we identified that the significant changes are observed in the
(A)
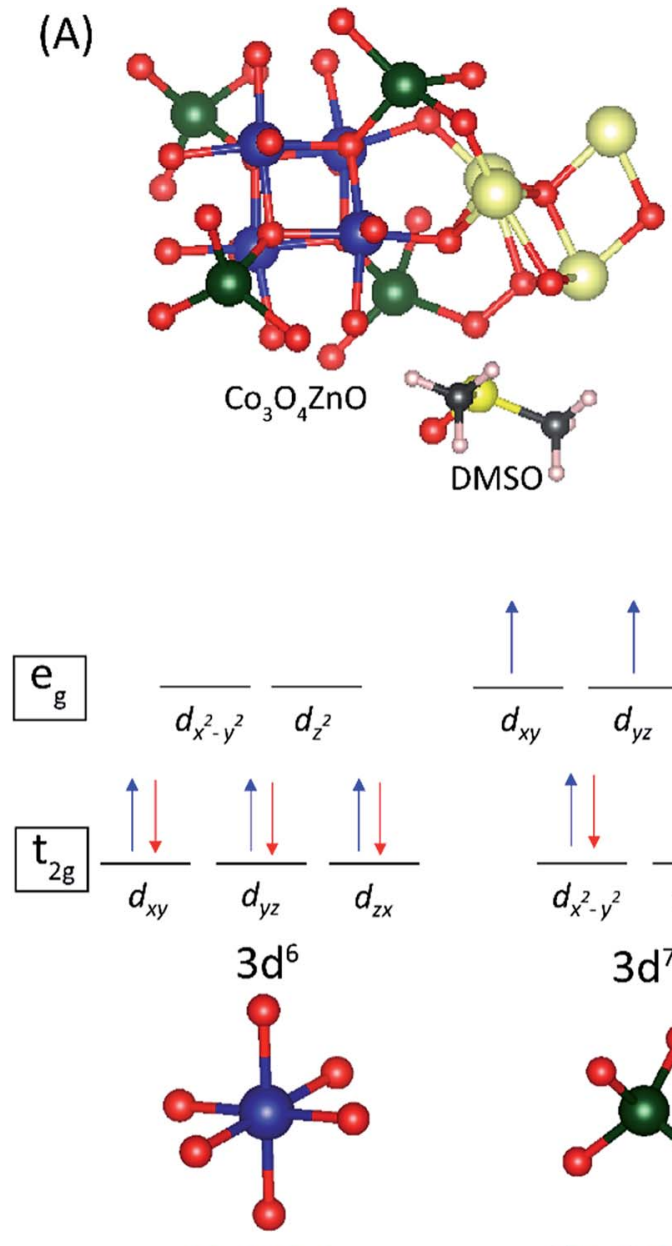

$\left[\mathrm{Co}^{3+} \mathrm{O}_{6}\right]_{\mathrm{Oh}}$
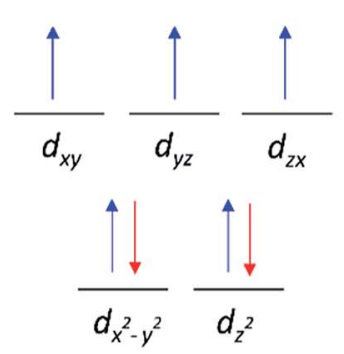

$3 d^{7}$

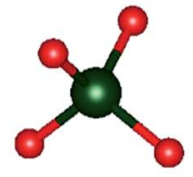

$\left[\mathrm{CO}^{2+} \mathrm{O}_{4}\right]_{\mathrm{Td}}$
(B)
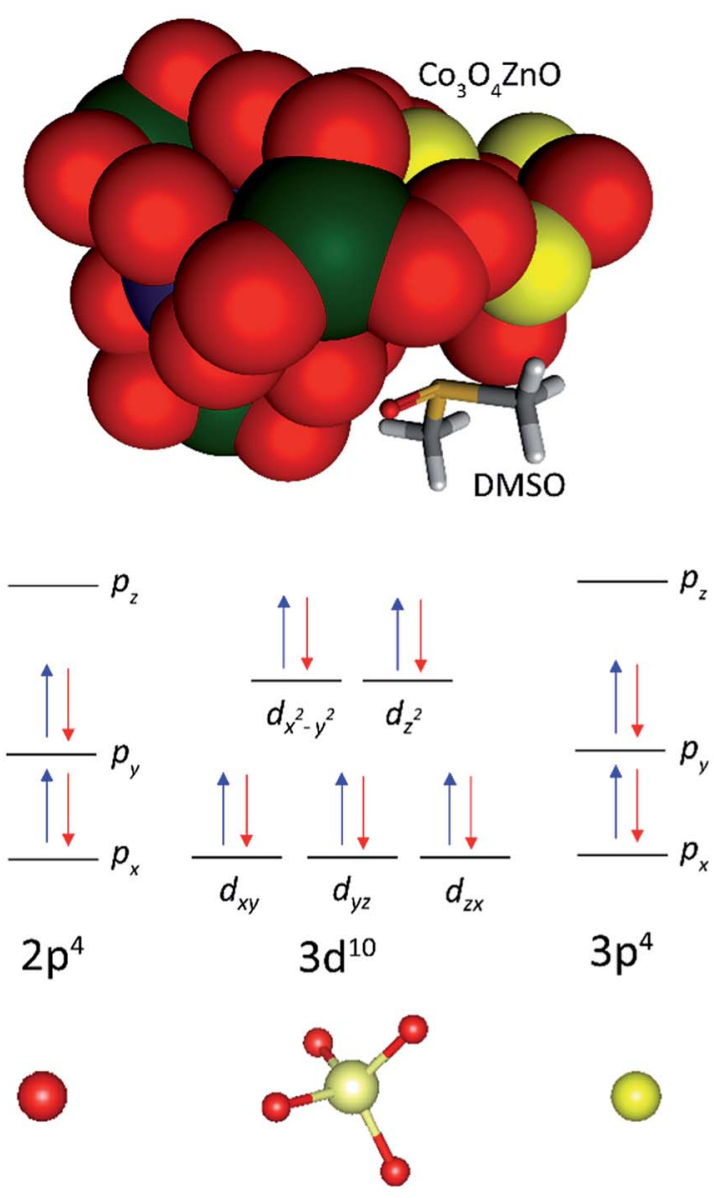

[O]
$3 p^{4}$

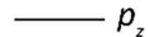

$[\mathrm{S}]_{\text {DMSO }}$

Fig. 13 The schematic representation of crystal field diagram of the global minimum energy geometry of $\left[\mathrm{CO}_{3} \mathrm{O}_{4}\right]_{4}[\mathrm{ZnO}]_{4} \mathrm{DMSO}$ adduct. 
orientations and distances between the $\mathrm{Co}_{3} \mathrm{O}_{4}$ and $\mathrm{ZnO}$ adducts. In model 1 , no bond formation observed and the nearest distance between the $\mathrm{Co}_{3} \mathrm{O}_{4}$ and $\mathrm{ZnO}$ adducts is found to be $2.527 \AA(\mathrm{Zn} \cdots \mathrm{O})$. Whereas in model $2, \mathrm{Co}_{3} \mathrm{O}_{4}$ and $\mathrm{ZnO}$ nanoclusters are approached so near to each other that they are linked together through the two $\mathrm{Zn}-\mathrm{O}$ bonds (2.065 and 2.149 $\mathrm{\AA}$ ) between a bridging oxygen atom of $\left[\mathrm{Co}_{3} \mathrm{O}_{4}\right]_{10}$ and a zinc atom of $[\mathrm{ZnO}]_{4}$ with $\mathrm{Co}-\mathrm{O}-\mathrm{Zn}$ oxo-linkage of $142.24^{\circ}$ and $120^{\circ}$ angles. Other two more close contacts with $2.24 \AA$ also found between $\mathrm{Zn}$ and $\mathrm{O}$ atoms. Interestingly, in model 3, two different bonds, $\mathrm{Zn}-\mathrm{O}: 1.935,2.552$ and $1.960 \AA$, between the zinc atoms of $[\mathrm{ZnO}]_{20}$ and oxygen atoms of $\left[\mathrm{Co}_{3} \mathrm{O}_{4}\right]_{10}$; Co-O: $2.197 \AA$, between the cobalt atom of $\left[\mathrm{Co}_{3} \mathrm{O}_{4}\right]_{10}$ and oxygen atom of $[\mathrm{ZnO}]_{20}$ are observed. The values of oxo-linkages angles $\mathrm{Zn}-\mathrm{O}-\mathrm{Co}: 144^{\circ}$, $149^{\circ}$ and $111^{\circ}$ and $94^{\circ}$ : Co-O-Zn are observed. Additionally, a short O-O (1.463 $⿱$ ) contact is also observed between the oxygen atoms of both adducts. Thus, from the computed structures of the adducts clearly suggested that as size of the interacted adducts increases more tightly they bound to each other via coordinate and covalent bonding and formed a single phase heterometallic nanomaterial. Further we have also demonstrated the corresponding frontier molecular orbitals of the model 1 and model 2, to explore the HOMO-LUMO gap and electronic properties (Fig. 11 and 12). The HOMO-LUMO gap is found to be $1.16 \mathrm{eV}$ in model 1 while $1.56 \mathrm{eV}$ in model 2 . In the model 1, HOMO, HOMO-1, HOMO-2, LUMO, LUMO+1 and $\mathrm{LUMO}+2$ are localized on the $\mathrm{ZnO}$ adduct while $\mathrm{HOMO}-3$ and $\mathrm{LUMO}+3$ on $\mathrm{Co}_{3} \mathrm{O}_{4}$ adduct (Fig. S5 $\uparrow$ and 11). Whereas in model 2, HOMO and LUMO are localized on the $\mathrm{ZnO}$ and $\mathrm{Co}_{3} \mathrm{O}_{4}$ adducts, respectively (Fig. 12).

We have also performed the geometry optimization of model 1 with the DMSO molecule, to find out the paramagnetic nature of the $\mathrm{Co}_{3} \mathrm{O}_{4} \mathrm{ZnO}$ adduct which cause the shifting of ${ }^{1} \mathrm{H}-\mathrm{NMR}$ peaks of DMSO. The $\mathrm{Co}_{3} \mathrm{O}_{4}$ structure comprises a cubic closepacked array of $\mathrm{O}^{-}$where $1 / 8$ of the tetrahedral interstices are occupied by high-spin $\mathrm{Co}^{2+}$, whereas half of the octahedral interstices are occupied by low-spin $\mathrm{Co}^{3+}$. Each $\mathrm{Co}^{2+}\left(\mathrm{e}_{\mathrm{g}}{ }^{4} \mathrm{t}_{2 \mathrm{~g}}{ }^{3}\right)$ is surrounded by four nearest neighbours of opposite spin, giving rise to an antiferromagnetic network. In contrast, the $\mathrm{Co}^{3+}$ exhibited a closed-shell configuration $\left(\mathrm{t}_{2 \mathrm{~g}}{ }^{6}\right)$ and nil magnetic moment, as depicted in Fig. 13. The global minimum energy geometry of model 1 with DMSO is illustrated in Fig. 13. The global minimum energy geometry indicated that in the presence of DMSO molecule the $\mathrm{ZnO}$ and $\mathrm{Co}_{3} \mathrm{O}_{4}$ adducts joined through the various $\mathrm{Zn}-\mathrm{O}-\mathrm{Co}$ linkage. Interestingly, $\mathrm{Zn}$ atom of $\mathrm{ZnO}$ adduct joined through the oxygen atoms of both types of $\mathrm{Co}^{2+}\left(T_{\mathrm{d}}\right)$ and $\mathrm{Co}^{3+}\left(\mathrm{O}_{\mathrm{h}}\right)$ ions of $\mathrm{Co}_{3} \mathrm{O}_{4}$ adduct (Fig. 13). Such kind of linkage may perturbed the antiferromagnetic coupling between the $\mathrm{Co}^{2+}\left(T_{\mathrm{d}}\right)$ ions or ligand field stabilization, which cause the paramagnetic nature of the $\mathrm{Co}_{3} \mathrm{O}_{4} \mathrm{ZnO}$ adduct and this paramagnetism cause the shifting of ${ }^{1} \mathrm{H}-\mathrm{NMR}$ peaks of DMSO as observed experimentally.

\section{Conclusion}

The present method for preparing nanoparticle precursors for homo- and heterometallic cores is more superior to other methods because we have used Werner's coordination theory reaction and reaction environment. One type of the nanocrystal was obtained, in comparison to other methods, which produce a mixture of nanoparticles with different shapes and sizes. This method is simple and suitable for nanocrystal design and tailoring. $\mathrm{Co}_{3} \mathrm{O}_{4}$ nanoparticles can be produced at a low temperature in the absence of solvent, surfactant and expensive or complicated equipment. The pure nanostructure $\mathrm{Co}_{3} \mathrm{O}_{4}$ and $\mathrm{ZnO} \cdot \mathrm{Co}_{3} \mathrm{O}_{4}$ particles with a size of $18-20 \mathrm{~nm}$ was successfully synthesized by the thermal decomposition of $\left[\mathrm{M}(\mathrm{II}) \mathrm{L}, \mathrm{L}^{\prime}\right]$ (where $\mathrm{M}=\mathrm{Co}(\mathrm{II}), \mathrm{Zn}$ (II) $\mathrm{L}=4$-hydroxy benzaldehyde and $\mathrm{L}^{\prime}=$ piperazine) complexes as new precursors. Nanoparticles were formed by redox reactions among the piperazine, benzaldehyde and counter ions. The rectangular/cubic rhomboid $\mathrm{Co}_{3} \mathrm{O}_{4}$ nanoparticles were obtained with agglomeration. DFT calculations support the formation and structure of the $\mathrm{ZnO} \cdot \mathrm{Co}_{3} \mathrm{O}_{4}$ and $\mathrm{Co}_{3} \mathrm{O}_{4}$. The model has been generated to understand the nano structures. Weak ferromagnetic behaviour was observed in the NMR chemical shift of methyl proton signals. The specific capacitance of the $\mathrm{ZnO} \cdot \mathrm{Co}_{3} \mathrm{O}_{4}$ and $\mathrm{Co}_{3} \mathrm{O}_{4}$ electrodes was calculated from the $\mathrm{CV} ; \mathrm{ZnO} \cdot \mathrm{Co}_{3} \mathrm{O}_{4}$ exhibited high capacitance which attributed to the better conductivity and surface area. DFT calculations with DMSO molecule further validated the experimental results displaying the paramagnetic nature of the $\mathrm{Co}$ (II) ion in $\mathrm{Co}_{3} \mathrm{O}_{4}$ adduct which caused the shifting of ${ }^{1} \mathrm{H}-\mathrm{NMR}$ peaks of DMSO.

\section{Conflicts of interest}

There is no conflicts to declare.

\section{Acknowledgements}

The authors acknowledge the financial support through Researchers Supporting Project number (RSP-2019/54), King Saud University, Riyadh, Saudi Arabia.

\section{References}

1 L. Hu, Q. Peng and Y. Li, J. Am. Chem. Soc., 2008, 130, 1613616137.

2 G. Wang, H. Wang, W. Li and J. Bai, RSC Adv., 2011, 1, 15851592.

3 T. A. Taton, Trends Biotechnol., 2002, 20, 277-279.

4 R. Atchudan, T. N. J. I. Edison, D. Chakradhar, N. Karthik, S. Perumal and Y. R. Lee, Ceram. Int., 2018, 44, 2869-2883.

5 C.-W. Kung, C.-Y. Lin, Y.-H. Lai, R. Vittal and K.-C. Ho, Biosens. Bioelectron., 2011, 27, 125-131.

6 M. El Baydi, G. Poillerat, J.-L. Rehspringer, J. L. Gautier, J.-F. Koenig and P. Chartier, J. Solid State Chem., 1994, 109, 281-288.

7 J. Ma, S. Zhang, W. Liu and Y. Zhao, J. Alloys Compd., 2010, 490, 647-651.

8 A. Rumplecker, F. Kleitz, E.-L. Salabas and F. Schüth, Chem. Mater., 2007, 19, 485-496.

9 A. Askarinejad and A. Morsali, Ultrason. Sonochem., 2009, 16, 124-131. 
10 T.-L. Lai, Y.-L. Lai, C.-C. Lee, Y.-Y. Shu and C.-B. Wang, Catal. Today, 2008, 131, 105-110.

11 C. Sun, X. Su, F. Xiao, C. Niu and J. Wang, Sens. Actuators, B, 2011, 157, 681-685.

12 P. Poizot, S. Laruelle, S. Grugeon, L. Dupont and J. M. Tarascon, Nature, 2000, 407, 496.

13 C. Klingshirn, ChemPhysChem, 2007, 8, 782-803.

14 A. Sulciute, J. Baltrusaitis and E. Valatka, J. Appl. Electrochem., 2015, 45, 405-417.

15 Z. Zhang, C. Shao, X. Li, C. Wang, M. Zhang and Y. Liu, ACS Appl. Mater. Interfaces, 2010, 2, 2915-2923.

16 C. W. Na, H.-S. Woo, I.-D. Kim and J.-H. Lee, Chem. Commun., 2011, 47, 5148-5150.

17 M. Salavati-Niasari, A. Khansari and F. Davar, Inorg. Chim. Acta, 2009, 362, 4937-4942.

18 G. M. Morris, R. Huey, W. Lindstrom, M. F. Sanner, R. K. Belew, D. S. Goodsell and A. J. Olson, J. Comput. Chem., 2009, 30, 2785-2791.

19 (a) F. Neese, Wiley Interdiscip. Rev.: Comput. Mol. Sci., 2012, 2, 73-78; (b) F. Neese, Orca, An ab Initio, Density Functional and Semiempirical Program Package version, 2009.

20 C. Lee, W. Yang and R. G. Parr, Phys. Rev. B, 1988, 37, 785789.

21 (a) F. Weigend and R. Ahlrichs, Phys. Chem. Chem. Phys., 2005, 7, 3297-3305; (b) A. Schaefer, C. Huber and R. Ahlrichs, J. Chem. Phys., 1994, 100, 5829-5835; (c)
A. Schaefer, H. Horn and R. Ahlrichs, J. Chem. Phys., 1992, 97, 2571-2577.

22 (a) S. Grimme, J. Antony, S. Ehrlich and H. Krieg, J. Chem. Phys., 2010, 132, 154104; (b) C. Steffen, K. Thomas, U. Huniar, A. Hellweg, O. Rubner and A. Schroer, J. Comput. Chem., 2010, 31, 2967-2970.

23 B. Pejova, A. Isahi, M. Najdoski and I. Grozdanov, Mater. Res. Bull., 2001, 36, 161-170.

24 R. K. Sharma and R. Ghose, J. Alloys Compd., 2016, 686, 6473.

25 B. D. Cullity and S. R. Stock, Elements of X-ray Diffraction, Prentice-Hall, New york, 3rd edn, 2001.

26 Y. Tak and K. Yong, J. Phys. Chem. C, 2008, 112, 74-79.

27 D. F. Evans, J. Chem. Soc., 1959, 2003-2005.

28 S. K. Sur, J. Magn. Reson., 1989, 82, 169-173.

29 N. Spataru, C. Terashima, K. Tokuhiro, I. Sutanto, D. A. Tryk, S.-M. Park and A. Fujishima, J. Electrochem. Soc., 2003, 150, E337-E341.

30 W.-J. Zhou, M.-W. Xu, D.-D. Zhao, C.-L. Xu and H.-L. Li, Microporous Mesoporous Mater., 2009, 117, 55-60.

31 J. Xu, L. Gao, J. Cao, W. Wang and Z. Chen, Electrochim. Acta, 2010, 56, 732-736.

32 V. Srinivasan and J. W. Weidner, J. Power Sources, 2002, 108, 15-20.

33 Y. Shang, T. Xie, C. Ma, L. Su, Y. Gai, J. Liu and L. Gong, Electrochim. Acta, 2018, 286, 103-113. 